\title{
Development of oncolytic virotherapy: from genetic modification to combination therapy
}

\author{
Qiaoshuai Lan ${ }^{1, *}$, Shuai Xia ${ }^{1, *}$, Qian Wang ${ }^{1}$, Wei Xu ${ }^{1}$, Haiyan Huang ${ }^{2}$, Shibo Jiang $(\bowtie)^{1,3}$, Lu Lu (凶) ${ }^{1}$ \\ ${ }^{1}$ Key Laboratory of Medical Molecular Virology (MOE/NHC/CAMS), School of Basic Medical Sciences and Shanghai Public Health Clinical \\ Center, Fudan University, Shanghai 200032, China; ${ }^{2}$ Yantai Yuhuangding Hospital, Qingdao University, Yantai 264000, China; ${ }^{3}$ Lindsley F. \\ Kimball Research Institute, New York Blood Center, New York, NY 10065, USA
}

(C) The Author(s) 2020. This article is published with open access at link.springer.com and journal.hep.com.cn

\begin{abstract}
Oncolytic virotherapy (OVT) is a novel form of immunotherapy using natural or genetically modified viruses to selectively replicate in and kill malignant cells. Many genetically modified oncolytic viruses (OVs) with enhanced tumor targeting, antitumor efficacy, and safety have been generated, and some of which have been assessed in clinical trials. Combining OVT with other immunotherapies can remarkably enhance the antitumor efficacy. In this work, we review the use of wild-type viruses in OVT and the strategies for OV genetic modification. We also review and discuss the combinations of OVT with other immunotherapies.
\end{abstract}

Keywords immunotherapy; oncolytic virus; genetic modification; immune checkpoint blockade; chimeric antigen receptor T cell

\section{Introduction}

Immunotherapy is an important antitumor therapy that involves stimulating or enhancing host antitumor immune response to kill and clear tumor cells [1,2]. Oncolytic virotherapy (OVT) is a new antitumor immunotherapy that uses natural or genetically modified viruses to selectively infect and kill tumor cells [3]. OVT has various advantages over current antitumor therapies. Oncolytic viruses (OVs) can selectively replicate in tumor cells with high safety [4] and carry foreign genes, such as therapeutic and immunostimulatory genes [5] for specific expression at tumor sites [6]. Some OVs can cross the blood-brain barrier (BBB) to kill brain tumor cells, such as reovirus [7] and parvovirus H-1 (H-1PV) [8], and OVs can turn "cold" tumors into "hot" tumors, thereby increasing the cellular sensitivity to other immunotherapies $[9,10]$. To date, many OVs, including DNA viruses, such as adenovirus (AdV) [11,12], vaccinia virus (VACV) [13,14], herpesvirus

Received November 21, 2019; accepted January 14, 2020

Correspondence: Shibo Jiang, shibojiang@fudan.edu.cn; Lu Lu, lul@fudan.edu.cn

${ }^{*}$ These authors contributed equally to this work.
[15,16], and parvovirus [17] and RNA viruses, such as reovirus $[18,19]$, Newcastle disease virus (NDV) [20], and measles virus (MV) [21] (Table 1) have been evaluated for cancer treatment (Fig. 1).

In the last century, scientists found that some viruses, such as NDV [32], MV [33], and parvovirus [34], can naturally kill tumor cells. However, during this period, OVs were derived from wild-type or naturally attenuated virus strains, leaving considerable room for improvement in their safety and antitumor effects $[35,36]$. In the 1990s, the emergence of recombinant DNA technology accelerated the development of OVT. Genetically modified OVs showed enhanced tumor targeting and killing efficiency against tumor cells with negligible damage to normal cells. The first genetically modified OV was herpes simplex virus (HSV)-1 developed by Martuza et al. in 1991 [37,38]. Oncorine (H101), a genetically modified oncolytic adenovirus (OAd), was approved by the State Food and Drug Administration (SFDA, now the National Medical Products Administration (NMPA)) in 2005 for the treatment of nasopharyngeal carcinoma in China $[39,40]$. Talimogene laherparepvec (T-VEC; brand name Imlygic) was approved by the US Food and Drug Administration (FDA) and European Medicines Agency (EMA) for the treatment of advanced melanoma in 2015 [41,42].

Researchers have recently attempted to combine OVT with other antitumor therapies, including chemotherapy 


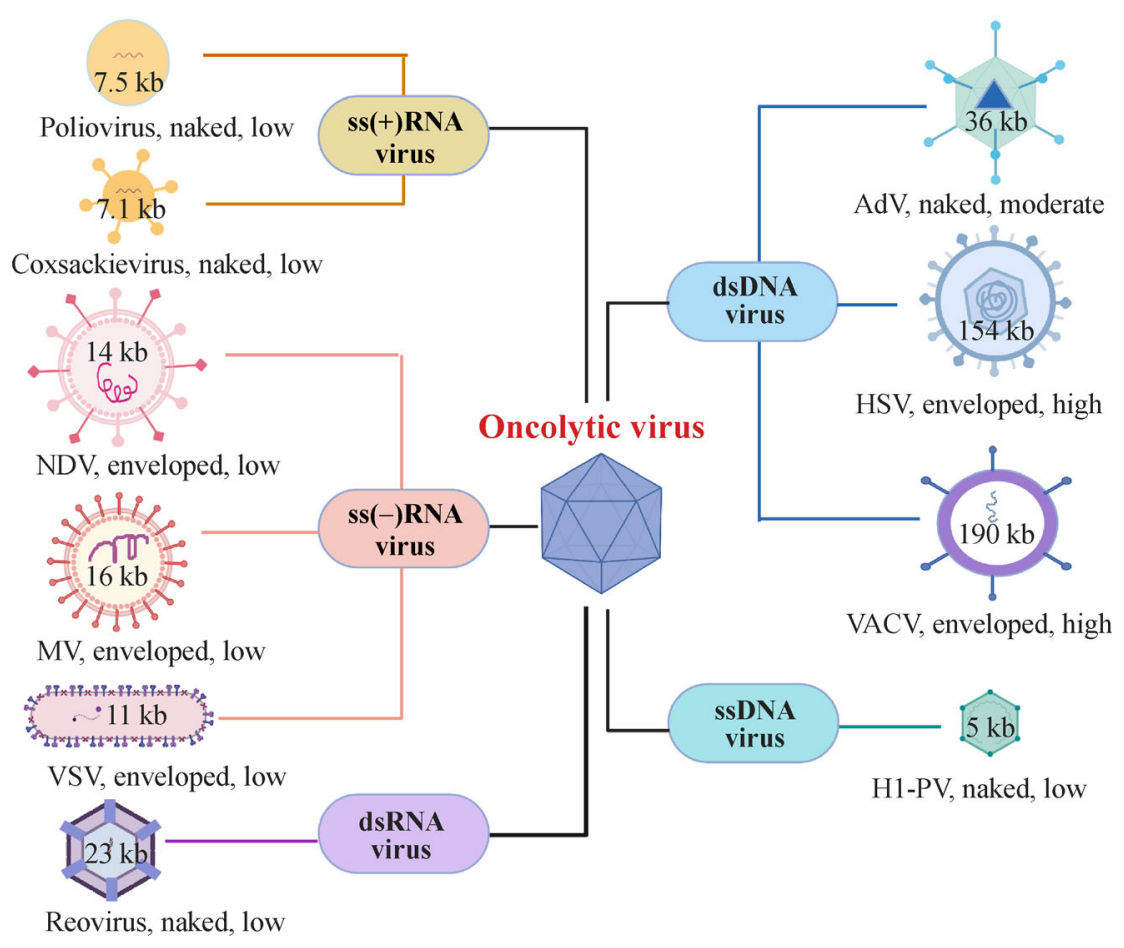

Fig. 1 Schematic of some oncolytic viruses for cancer treatment. Many viruses, including double-stranded DNA viruses, such as AdV, herpes simplex virus (HSV), and VACV; single-stranded DNA viruses, such as parvovirus; negative-sense single-stranded RNA viruses, such as Newcastle disease virus (NDV), measles virus (MV), and vesicular stomatitis virus (VSV); positive-sense single-stranded RNA viruses, such as poliovirus and coxsackievirus; and double-stranded RNA viruses, such as reovirus, have been used in cancer treatment. The terms naked/enveloped are used to describe types of virus; high/moderate/low describes the genomic capacities of OVs.

[43-45], radiotherapy [46,47], small molecules $[48,49]$, and other immunotherapies [50,51], to achieve increased therapeutic effects against tumors. Among these treatments, the combination of OVT with other immunotherapies, especially regimens involving immune checkpoint inhibitors (ICIs) and chimeric antigen receptor-engineered $\mathrm{T}$ cell (CAR-T cell) immunotherapies, has shown promise as a cancer treatment [51,52]. OVs can "heat up" tumors, thus enhancing their sensitivity to ICIs [53]. OVs can also piggyback CAR-T cells in a manner that enables them to overcome the immunosuppressive tumor microenvironment (TME) and increase their antitumor activity against solid tumors [54]. Recently, natural OVs have been continuously identified and widely applied in OVT. The renewed development of genetically modified OVs with enhanced tumor-targeting ability, antitumor efficacy, and safety has further promoted the development of OVT. In this work, we review the applications of wild-type viruses and the modifications for improving the tumor-targeting ability, antitumor efficacy, and safety of OVs. We also review and discuss the important research directions for OVT combination with other immunotherapies, including immune checkpoint blockade (ICB) and CAR-T cell therapies.

\section{Wild-type OVs in oncolytic virotherapy}

Some wild-type OVs have a natural tropism for tumor cells based on their capacity to recognize highly expressed receptors on tumor cell surfaces or based on abnormal pathways or products in tumor cells, such as a defect in the interferon (IFN) signaling pathway and the activated Ras pathway. Among them, several representative OVs, such as coxsackievirus [55], parvovirus [56], and reovirus [57], have been widely reported.

Coxsackievirus A21 (CVA21) is a promising OV that depends on highly expressed receptor molecules on the surface of tumor cells, intercellular adhesion molecule-1 (ICAM-1, also named CD54), and decay-accelerating factor to preferentially enter, replicate in, and kill tumor cells. CVA21 exhibited antitumor efficacy in multiple cancers, including melanoma, prostate cancer, and multiple myeloma [30]. A CVA21-based OV (CAVATAK $\left.{ }^{\circledR}\right)$ has been assessed in clinical trials for the treatment of malignant melanoma, bladder cancer [58], and uveal melanoma with liver metastases [59]. The results revealed that CAVATAK $^{\circledR}$ has a good safety profile and can stimulate systemic antitumor immunity for the treatment of patients with melanoma [60]. CAVATAK ${ }^{\circledR}$ can also 
Table 1 Characteristics of DNA virus- and RNA virus-derived OVs

\begin{tabular}{|c|c|c|c|c|c|c|c|}
\hline Virus type & Virus & Family & $\begin{array}{c}\text { Natural } \\
\text { host }\end{array}$ & Receptor & Replication site & $\begin{array}{l}\text { Common used virus } \\
\text { strain or type }\end{array}$ & References \\
\hline \multirow[t]{4}{*}{ DNA virus } & Adenovirus & Adenoviridae & Human & CAR, integrin & $\begin{array}{l}\text { Nucleus, } \\
\text { cytoplasm }\end{array}$ & Ad5 & {$[22]$} \\
\hline & Vaccinia virus & Poxviridae & Human & Unknown & Cytoplasm & Lister, Wyeth, WR & {$[23]$} \\
\hline & Herpesvirus & Herpesviridae & Human & $\begin{array}{r}\text { HVEM, } \\
\text { nectin }\end{array}$ & $\begin{array}{l}\text { Nucleus, } \\
\text { cytoplasm }\end{array}$ & HSV-1 & {$[24]$} \\
\hline & Parvovirus & Parvoviridae & Rat & SARs & $\begin{array}{l}\text { Nucleus, } \\
\text { cytoplasm }\end{array}$ & H1-PV & {$[25]$} \\
\hline \multirow[t]{6}{*}{ RNA virus } & Measles virus & Paramyxoviridae & Human & CD46, SLAM & Cytoplasm & $\begin{array}{l}\text { Edmonston vaccine } \\
\text { strain }\end{array}$ & {$[26]$} \\
\hline & $\begin{array}{l}\text { Newcastle } \\
\text { disease virus }\end{array}$ & Paramyxoviridae & Chicken & Unknown & Cytoplasm & HUJ, MTH-68/H & {$[27]$} \\
\hline & $\begin{array}{l}\text { Vesicular } \\
\text { stomatitis } \\
\text { virus }\end{array}$ & Rhabdoviridae & $\begin{array}{l}\text { Pigs, cattle, } \\
\text { horses }\end{array}$ & LDLR & Cytoplasm & $\begin{array}{l}\text { Recombinant Indiana } \\
\text { strain }\end{array}$ & {$[28]$} \\
\hline & Poliovirus & Picornaviridae & Human & CD155 & Cytoplasm & Sabin vaccine strain & [29] \\
\hline & Coxsackievirus & Picornaviridae & Human & $\begin{array}{l}\text { ICAM-1, } \\
\text { DAF }\end{array}$ & Cytoplasm & CVA21, CVB3 & {$[30]$} \\
\hline & Reovirus & Reoviridae & Human & Unknown & Cytoplasm & Reovirus-serotype 3 & {$[31]$} \\
\hline
\end{tabular}

CAR, coxsackie adenovirus receptor; HVEM, herpesvirus entry mediator; SARs, sialic acid residues; SLAM, signaling lymphocytic activation molecule; LDLR, low-density lipoprotein receptor; ICAM-1, intercellular adhesion molecule 1; DAF, decay accelerating factor.

induce immune cells to infiltrate the TME, indicating that its use in combination with other antitumor immunotherapies can increase antitumor efficacy.

Wild-type H-1PV exhibits tumor selectivity, mainly depending on tumor-specific abnormal replication and transcription factors and the defective type I IFN-mediated antiviral pathway in tumor cells [17]. H-1PV nonstructural protein 1 (NS1) is important for promoting tumor cell death. Preclinical studies suggested that H-1PV can effectively kill various tumor cells [56], including pancreatic ductal adenocarcinoma cells and glioma cells [61]. In particular, ParvOryx (wild-type H-1PV) showed an excellent safety profile in phase I/IIa clinical trials [8]. Wild-type reovirus can also selectively replicate in tumor cells in association with the abnormally activated Ras pathway in tumor cells [62]. Reovirus can cross the BBB to kill brain tumor cells through intravenous administration [7]. Reolysin ${ }^{\circledR}$ (pelareorep) is a formulation of the reovirus serotype 3 Dearing strain and is being assessed in clinical trials for the treatment of multiple myeloma [63], pancreatic adenocarcinoma [64], and melanoma [65]. Reolysin ${ }^{\circledR}$ has received an orphan drug designation from the US FDA and EMA for the treatment of gastric and pancreatic cancers [31]. In the treatment of multiple myeloma, the single use of Reolysin ${ }^{\circledR}$ did not show obvious antitumor activity [66]. However, when Reoly$\sin { }^{\circledR}$ was combined with chemotherapy, such as carboplatin and paclitaxel, it exhibited improved therapeutic efficacy with an objective response rate (ORR) of up to $21 \%$ in the treatment of malignant melanoma [19].
Many alphaviruses, such as Semliki Forest virus (SFV) [67,68], Sindbis virus (SINV) [69], and M1, exhibit antitumor activity. M1 is a recently identified Getah-like alphavirus from culicine mosquitoes [70,71]. M1 has tumor selectivity related to zinc-finger antiviral protein (ZAP) deficiency in tumor cells and therefore can selectively replicate in tumor cells and induce apoptosis of the infected tumor cells by inducing irreversible endoplasmic reticulum (ER) stress [72]. M1 showed high tumor cell selectivity and tumor-killing activity during in vitro and in vivo experiments [73]. Moreover, its antitumor activity can be considerably increased by targeted inhibitors, such as valosin-containing protein (VCP) inhibitor and DNA-dependent kinase (DNA-PK) inhibitor [74,75], suggesting that combining M1 with these inhibitors is an important strategy.

\section{Genetic modifications of OVs}

Genetic modification has accelerated the development of OVT [76]. In 1991, the first study reported on a genetically engineered $\mathrm{OV}$, that is, an HSV with thymidine kinase (TK) deletion [38]. Many genetically modified OVs have been evaluated in clinical trials, as shown in Table 2; such OVs include AdV, VACV, and HSV. OVs mainly genetically modified through the deletion of virulence genes to improve the safety and insertion of foreign genes and improve antitumor efficacy or tumor targeting ability of OVs [77]. The genetic modifications of OVs can be 
classified into four categories according to purpose: (1) enhancing tumor targeting, (2) improving the safety of OVs, (3) increasing antitumor efficacy, and (4) monitoring replication status of OVs in vivo [78] (Fig. 2).

\section{Enhancing tumor targeting}

The tumor tropism of OVs is an important feature to ensure that they selectively replicate in and specifically kill tumor cells [79]. Wild-type OVs generally depend on tumorspecific cellular receptors or abnormal intracellular pathways and products to enter and selectively replicate in tumor cells and therefore can be optimized through genetic modifications to enhance their tumor targeting. Many genetically engineered OVs with enhanced tumor cell targeting ability have been developed on the basis of the tumor-specific high expression of certain receptors and the abnormal intracellular signaling pathways and metabolic status [80].

\section{Engineered tumor tropism targeting specific tumor surface receptors}

The nonspecificity, low affinity, or low expression of natural viral receptors on tumor cells can limit the application of wild-type OVs. Thus, OVs should be genetically modified to increase their binding affinity to specifically expressed receptors on tumor cells and increase their efficiency in entering and targeting tumor cells.

Inserting targeting peptides can improve the entry efficiency of OVs [81]. For example, adenovirus type 5 (Ad5) is a widely used OV vector, but its receptor, coxsackie adenovirus receptor (CAR), is not highly expressed in many tumor cells [22]; this phenomenon leads to the low entry efficiency of OAd. Through genetic engineering, an arginine-glycine-aspartic acid (RGD) motif was inserted into the fiber knob domain of Ad5 to generate a newly modified virus, which no longer depends on CAR to enter tumor cells and instead relies on integrins that are highly expressed on tumor cells, to enter tumor cells [82]. Other studies inserted the fiber knob domain derived from adenovirus type $3(\mathrm{Ad} 3)$ into the backbone of Ad5 (also named serotype switching) to allow its entrance to the tumor cells by utilizing the highly expressed Ad3 receptor (desmoglein 2 as the primary receptor) on tumor cells to enter the tumor cells [79]. A similar modification involves inserting the fiber knob domain of adenovirus type 35 (Ad35) into the backbone of Ad5, allowing the OVs to utilize the Ad35 receptor (CD46 as the primary receptor) to enter tumor cells [81].

Some envelope glycoproteins $(G)$ from other virus families can be inserted to improve tumor cell targeting.
Betancourt et al. [83] reported replacing the G protein of vesicular stomatitis virus (VSV) with human immunodeficiency virus type 1 (HIV-1) gp160 to generate a new OV (VSV-gp160G); this method abandons the natural tissue tropism of VSV and specifically targets the new receptor, CD4. VSV-gp160G does not damage normal CD4 T cells; however, it exhibits potent killing activity against CD4expressing tumor cells, such as adult $\mathrm{T}$ cell leukemia/ lymphoma cell lines, in association with defective antiviral immune pathways in these tumor cells. A gene encoding a single-chain antibody ( $\mathrm{scAb}$ ) targeting human epidermal growth factor receptor 2 (HER2) was incorporated into HSV-1, making it fully targeted to tumor cells expressing HER2, and HER2-negative cells were left unharmed [8486]. This modification also enhanced safety. Insertions of $\mathrm{scAb}$ targeting tumor-surface antigens, such as epithelial cell adhesion molecule (EpCAM) [87] and human carcinoembryonic antigen (CEA) [88], have been reported to improve the tumor targeting of OVs. Shibata et al. [87] reported the insertion of the scAb targeting EpCAM (scEpCAM) into the HSV-1 genome. The engineered virus is highly specific to the EpCAM expressed on the surface of tumor cells to enter tumor cells; it can efficiently and specifically kill tumor cells expressing EpCAM. This strategy can improve the tumor targeting of OVs. However, these OVs have not yet entered clinical trials, and their clinical efficacy needs to be further confirmed.

\section{Engineered tumor tropism targeting the intracellular abnormalities of tumor cells}

The various signaling pathways and the metabolic status of tumor cells are altered compared with those of normal cells [89]. Many features of tumor cells can be utilized by OVs to generate tumor selectivity [90]; such features include defective antiviral pathways, such as a defective type I IFN signaling pathway [91]; the loss of expression of tumor suppressor genes, such as loss of the retinoblastoma gene [92]; and elevated signaling pathways, such as a transformed Ras pathway [93]. Therefore, targeting these abnormal pathways or products in tumor cells, deleted virulence factors and inserted tumor-specific promoters or microRNA-targeting sequences (miRNA-TSs) of OVs can regulate OVs specifically replicating in tumor cells $[94,95]$. Deletion of virulence factors can improve the safety of OVs, which is discussed in the next section on the safety of genetically modified OVs. This section introduces the strategies for inserting tumor-specific promoters or miRNA-TSs to improve the tumor targeting of OVs.

Insertion of tumor-specific promoters, such as the human telomerase reverse transcriptase (hTERT) promoter [96] and the prostate-specific antigen (PSA) promoter [97], can improve the tumor selectivity of OVs [3], which will, in turn, drive the expression of viral genes in tumor cells 


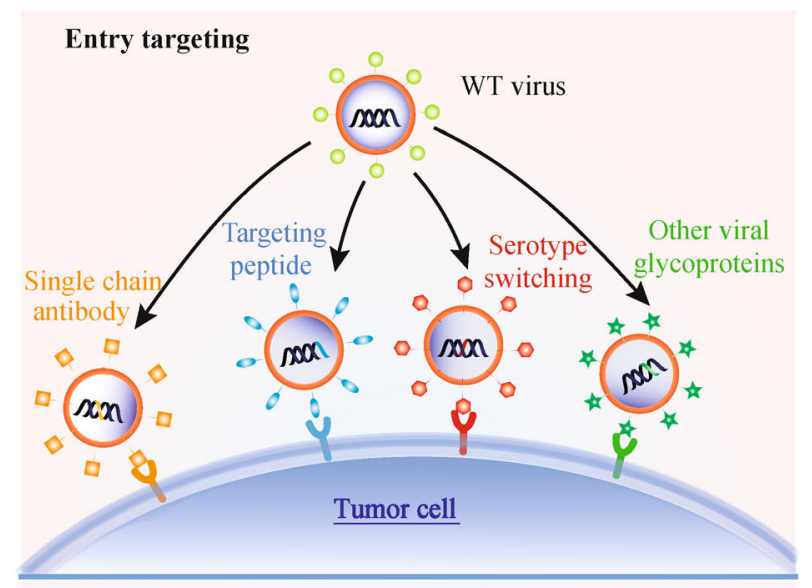

Post-entry targeting

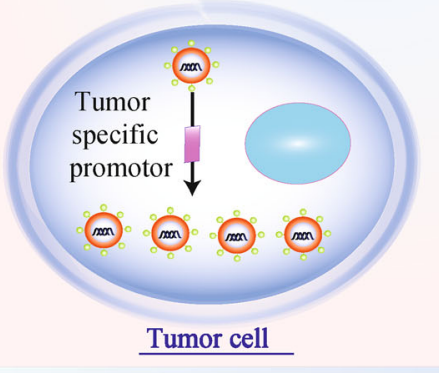

\section{A. Improving tumor targeting}

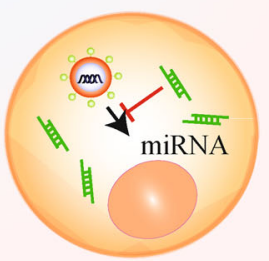

Normal cell

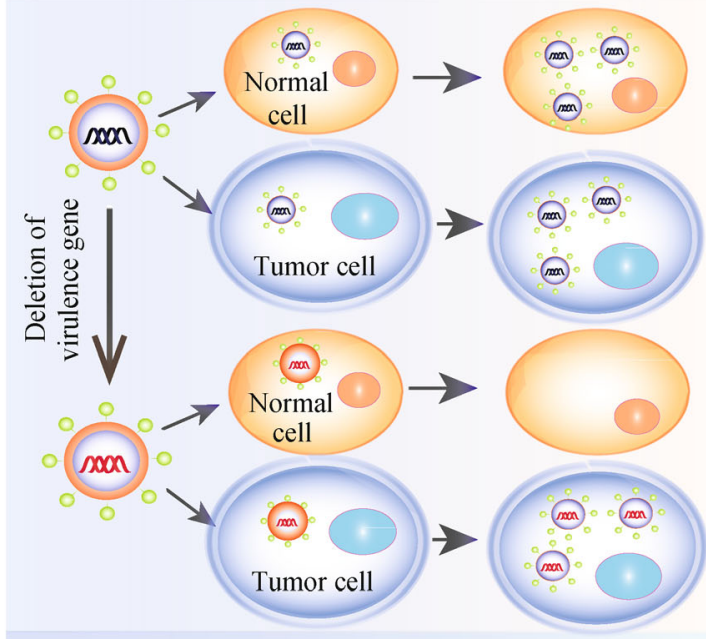

B. Enhancing safety of OVs

\section{Improving antitumor efficacy}

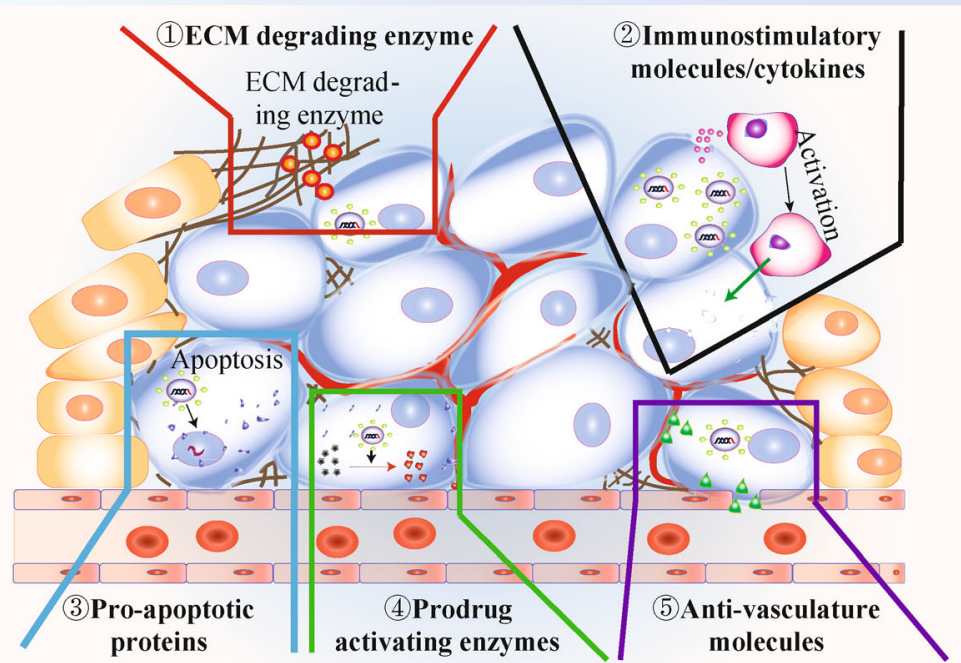

\section{Monitoring replication of OVs}

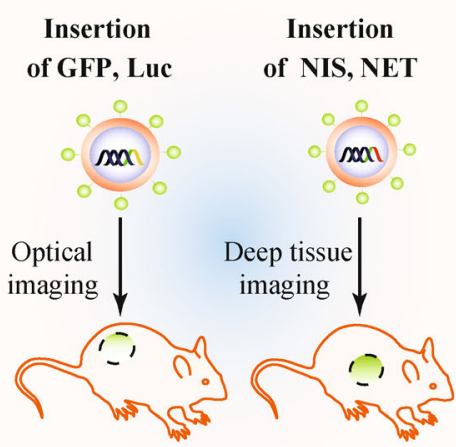

Fig. 2 Genetic modifications of OVs. (A) Genetic modifications for improving tumor targeting of OVs. Entry targeting: serotype switching and insertion of a tumor-targeting peptide, glycoproteins from other viruses, and single-chain antibodies (scAb) targeting tumor-associated antigens can allow OVs to target tumor surface molecules and enter tumor cells. Post-entry targeting: insertion of tumor-specific promotors can promote virus replication in tumor cells, while insertion of miRNA target sequences can restrict virus replication in normal cells. (B) Genetic modifications that enhance OV safety. Deletion of virulence genes can reduce the risk of OV infections of normal cells and enhance safety. (C) Genetic modifications to augment the antitumor efficacy of OVs. Antitumor efficacy can be augmented by inserting foreign genes, such as genes encoding immunostimulatory molecules/cytokines, suicide genes (pro-apoptotic proteins and prodrug-activating enzymes), extracellular matrix (ECM)-degrading enzymes, and anti-vasculature molecules. (D) Genetic modifications to monitor OV replication. Reporter genes, such as green fluorescent protein (GFP), Renilla luciferase (Rluc), sodium-iodide symporter (NIS), and human norepinephrine transporter (NET), can be inserted to monitor OV replication. 


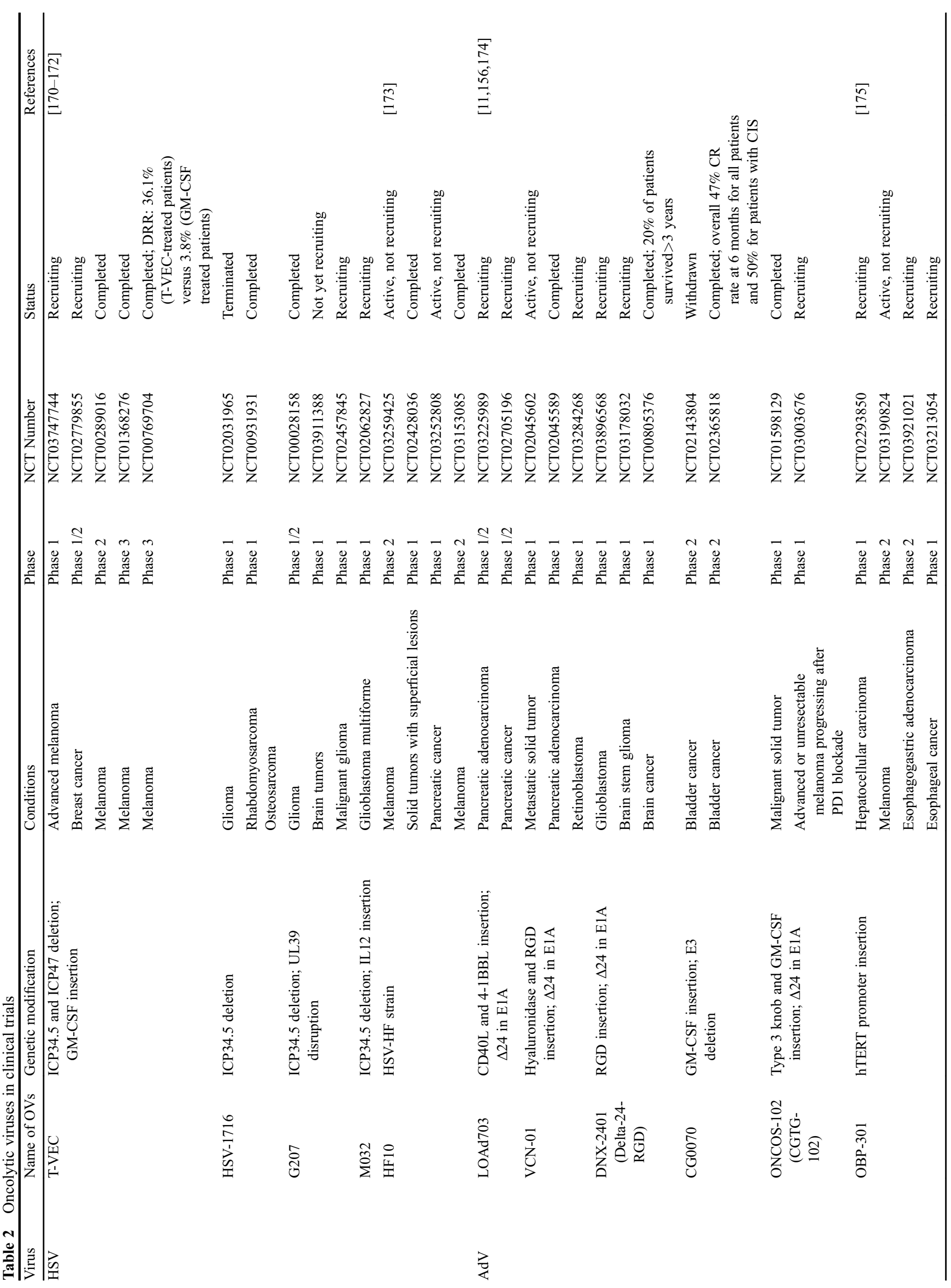



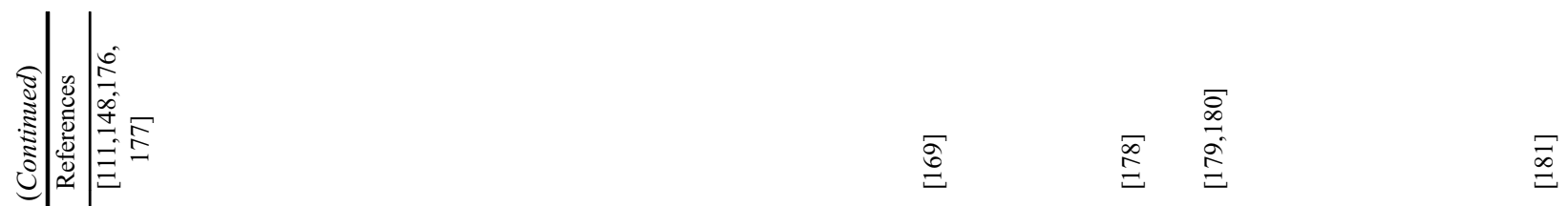

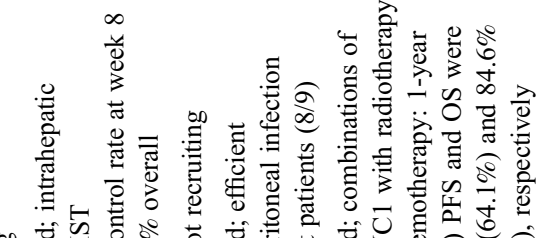

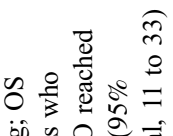

$\stackrel{\infty}{\rightleftharpoons}$

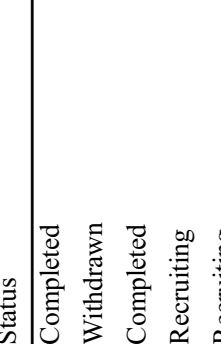

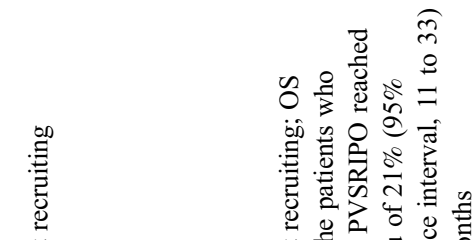

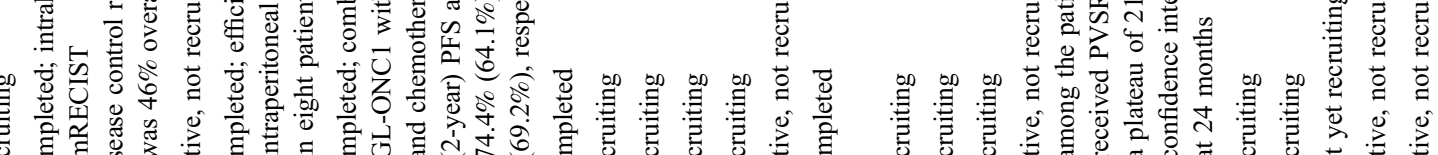
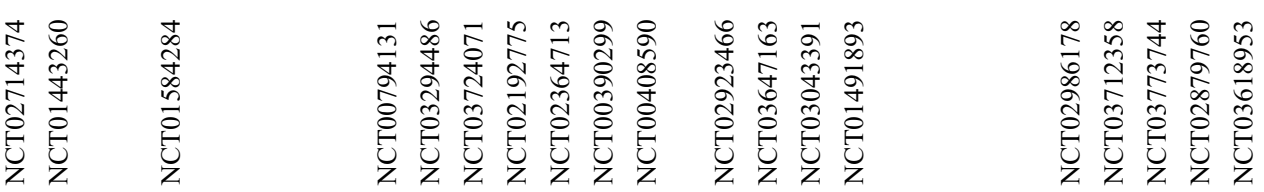

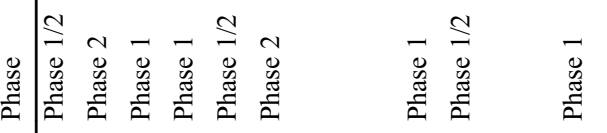
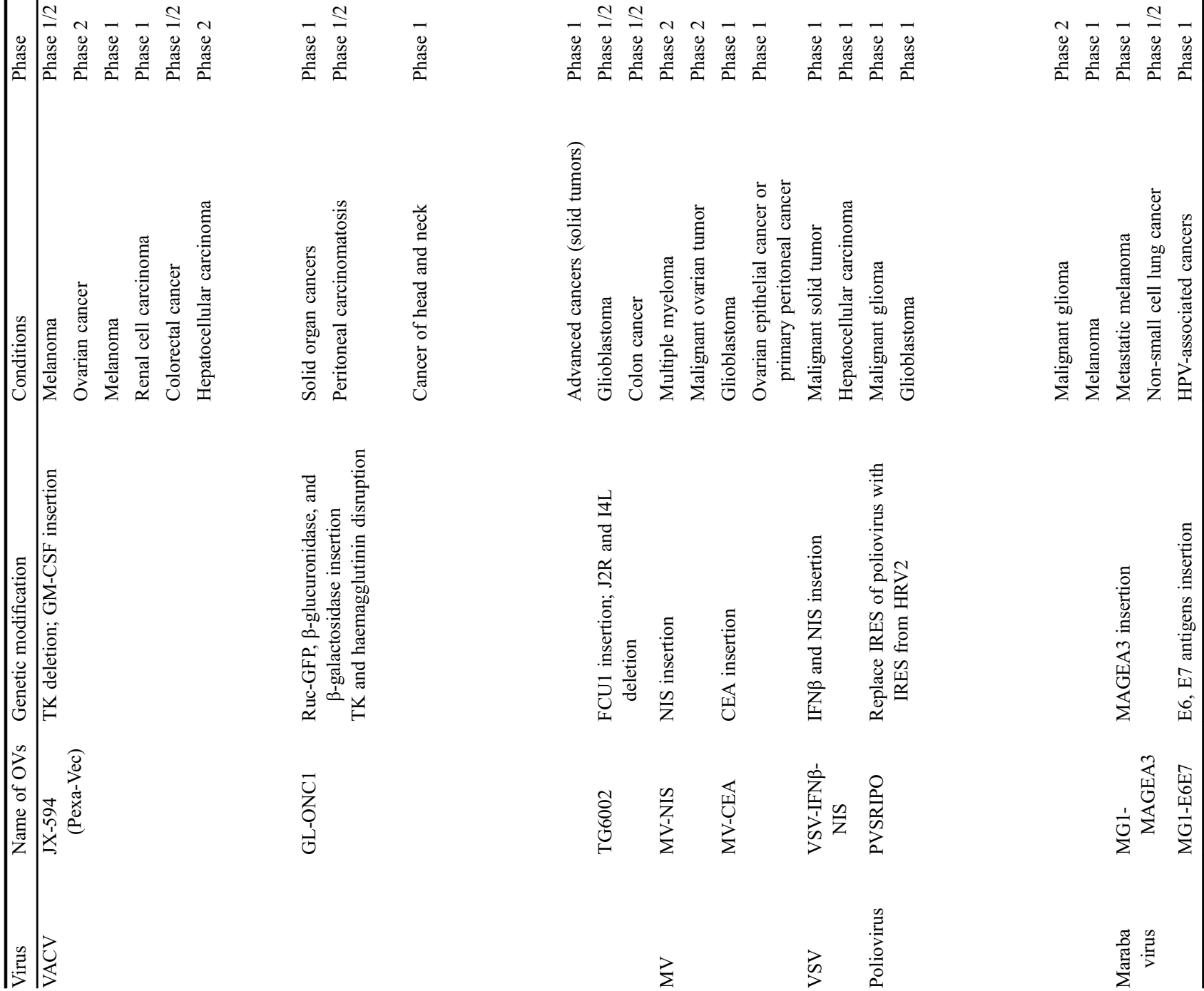

范

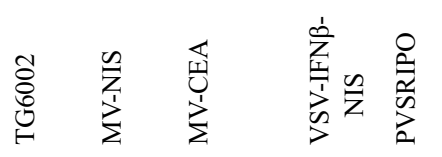

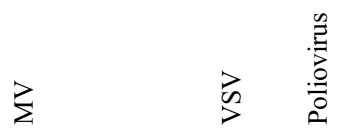

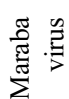




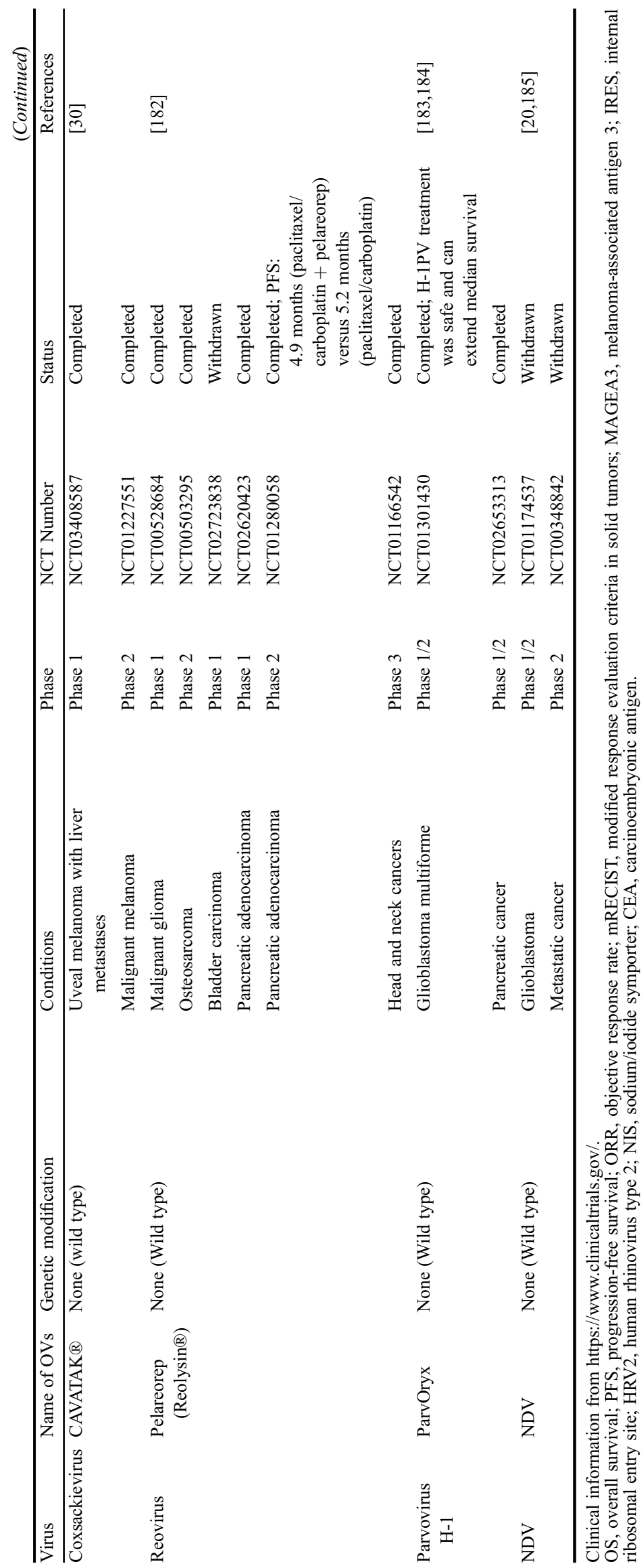


but not in normal cells. As an example, hTERT is highly expressed in most tumor cells but absent in normal cells [98]; hence, the inserted hTERT promoter in OVs can initiate viral gene expression and replication in tumor cells with high hTERT expression [99]. OBP-301, an OAd with an inserted hTERT promoter, can replicate in tumor cells specifically, such as renal cell carcinoma cells and prostate cancer cells [100].

Different from the mechanisms of action of inserted tumor-specific promoters, inserted miRNA-TSs can lead to the viral RNA degradation through miRNAs in normal tissues; therefore, engineered OVs can specifically replicate in tumor cells with low miRNA expression $[101,102]$. For example, targeting downregulated miRNA-7 in glioblastoma multiforme (GBM), researchers constructed a miRNA-7-sensitive oncolytic MV that specifically infects glioma cells without damaging normal cells [103].

\section{Improving the safety of OVs}

The safety of OVs is important for their clinical use. Some natural viruses have the potential to kill tumor cells but can also damage normal cells. Numerous studies have suggested that the deletion of some genes necessary for viral replication in normal cells or virulence genes can improve OV safety in normal cells and maintain their oncolytic capacities; such genes include TK in oncolytic VACV [104,105] and ICP34.5 in oncolytic HSV-1 $[106,107]$.

The viral products encoded by such genes are required for the replication of some OVs in normal cells, and they are abundant in tumor cells. Therefore, OVs can utilize tumor cell products to selectively replicate, but they cannot replicate in normal cells because relevant products are lacking. For example, TK, an important enzyme for nucleotide synthesis, is highly expressed in tumor cells [108] but only expressed at a low level in normal cells. TK encoded by VACV is essential for viral replication in normal cells. The deletion of the TK gene is an important genetic modification of oncolytic VACV [109,110] to improve its safety. Oncolytic VACV with TK deletion can replicate in tumor cells but not in normal cells. Therefore, TK deletion can increase the safety of oncolytic VACV. Some oncolytic VACVs, such as GL-ONC1 and Pexa-Vec (JX-594), currently being assessed in clinical trials have TK deletions. GL-ONC1 has been assessed in clinical trials for the treatment of patients with peritoneal carcinomatosis (phase I/II) or cancer of the head and neck (phase I). Phase I clinical trial of GL-ONC1 for the treatment of peritoneal carcinomatosis $[13,111]$ showed its improved safety but also the emergence of minor adverse events. Phase II clinical trial results for Pexa-Vec showed that it could improve the survival of patients with liver cancer [14]; thus, this OV has now entered phase III clinical trials for the treatment of hepatocellular carcinoma.
Wild-type HSV-1 can cause latent infections in normal neurons, but the deletion of its neurovirulence factor (ICP34.5) can enhance its safety [112]. ICP34.5 antagonizes protein kinase $\mathrm{R}$ (PKR)-mediated immune response and is essential for infecting neurons. Oncolytic HSV with ICP34.5 deletion cannot replicate in neurons [24]. Given that PKR is usually downregulated in tumor cells, the virus can replicate normally in these tumor cells. HSV-1716, G207, and T-VEC are oncolytic HSVs with ICP34.5 deletions. T-VEC has been approved by the US FDA for the treatment of melanoma [113]. In a recent study, the ORR among patients with in-transit melanoma metastasis treated with T-VEC was $40.7 \%$ [114].

Zika virus (ZIKV) was recently found to have oncolytic properties [115], but ZIKV infections in children can cause serious consequences [116,117]. Wild-type ZIKV could infect glioblastoma stem cells (GSCs; an important target for glioblastoma treatment) and slow down the growth of tumors, but wild-type ZIKV also attacks normal nerve cells [115]; hence, its safety should be further improved. A liveattenuated ZIKV vaccine (ZIKV-LAV) candidate [118] with 10 nucleotide deletions in the $3^{\prime}$ untranslated region in the ZIKV genome can maintain its oncolytic activity with increased safety and gene stability $[119,120]$. In preclinical research, ZIKV-LAV effectively inhibited GSC growth and improved the survival of experimental animals compared with the mock control group. The median survival time of mice transplanted with 387 GSC cells was extended from 30 days to 48 days, while the median survival time of mice transplanted with 4121 GSC cells increased from 31 days to 53 days [119].

\section{Augmenting antitumor efficacy}

OVs can kill tumor cells through the following mechanisms: selectively replicating in tumor cells and causing the oncolysis of tumor cells [121]; inducing the immunogenic cell death of tumor cells, thereby releasing damageassociated molecular pattern molecules, tumor-associated antigens, and pathogen-associated molecule patterns that stimulate antitumor immunity to kill other tumor cells [91]; and destroying tumor vasculature to indirectly kill tumor cells $[122,123]$. Insertion of genes coding for immunostimulatory molecules/cytokines, suicide genes, ECMdegrading enzymes, and anti-vasculature molecules can improve the antitumor efficacy of OVs $[76,124,125]$.

\section{Immunostimulatory molecules/cytokines}

OVs induce systemic antitumor immunity, and many cytokines, such as granulocyte-macrophage colony-stimulating factor (GM-CSF) and interleukin (IL)-12 can increase the antitumor immunity. Thus, many OVs have been armed with immunostimulatory cytokines to improve 
their therapeutic efficacy [126]. For example, GM-CSF can recruit antigen-presenting cells (APCs) and promote the presentation of tumor antigens [78]. Various OVs armed with GM-CSF, including T-VEC (HSV-1), Pexa-Vec (VACV), and CG0070 (AdV), have been evaluated in clinical trials. IL-12 can stimulate IFN- $\gamma$ production, enhance the effect of $\mathrm{T}$ cells, and promote antitumor activity [127]. M032 is an oncolytic HSV expressing IL-12 [128] and is being assessed in the clinical trial for the treatment of GBM (the results of which have not yet been reported). Other cytokines, such as IL-2 [129] and IL-15 [130], can also be inserted to improve antitumor efficiency. However, some secreted cytokines have systemic toxicity [131]. Liu et al. [132] have developed a new strategy to solve the side effects of the systemic administration of cytokines. They used membrane-bound IL-2, instead of secretory IL-2, to construct an oncolytic VACV that expresses membrane-bound IL-2 (named vvDD-IL-2-RG). Compared with the oncolytic VACV- expressing secretory IL-2, vvDD-IL-2-RG did not compromise antitumor activity and its toxicity was remarkably reduced.

Inserting other immunostimulatory molecules, such as the costimulatory molecules CD40 ligand (CD40L) and 41BB ligand (4-1BBL), has also enhanced the antitumor effects of OVs $[133,134]$. CD40 and 4-1BB belong to the tumor necrosis factor receptor (TNFR) superfamily. CD40 and 4-1BBL expressed on the surface of APCs and other cells can recognize and bind CD40L and $4-1 \mathrm{BB}$ on the surface of $\mathrm{T}$ cells, respectively, enhancing the ability of APCs to present antigens and promote $\mathrm{T}$ cell activation [135]. The recombinant adenovirus LOAd703 simultaneously expresses the immunostimulatory molecules CD40L and 4-1BBL [136], resulting in the effective activation of $\mathrm{T}$ cells through the CD40 and 4-1BB signaling pathways, respectively; as such, they can enhance antitumor immunity. LOAd703 has entered clinical trials for the treatment of pancreatic cancer [137] but the results have not yet been reported.

\section{Suicide gene}

Suicide gene therapy includes two strategies: expressing pro-apoptotic proteins or toxin proteins to kill tumor cells directly and using prodrug-activating systems to kill tumor cells indirectly [138]. Engineered OVs can express proapoptotic proteins or toxin proteins to directly kill tumor cells, such as tumor necrosis factor-related apoptosisinducing ligand (TRAIL) [139,140] and apoptin [141]. TRAIL can induce the apoptosis of tumor cells but does not damage normal cells [142]. Zhu et al. constructed a TRAIL-expressing OAd, which can efficiently kill triplenegative breast cancer cell lines in vitro without damaging normal cells and efficiently inhibit the growth of tumors in animal experiments [139]. Similarly, apoptin can induce the apoptosis of tumor cells but not that of normal cells, and apoptin-expressing OAd can effectively inhibit the growth of gastric carcinoma cells [143].

Conventional chemotherapies lack tumor selectivity and can cause damage to normal cells [144]. By contrast, virusdirected enzyme prodrug therapy is an ideal choice as it involves prodrug-activating enzymes expressed by recombinant OVs to turn nontoxic prodrugs into toxic drugs to specifically kill tumor cells [145]. TK and cytosine deaminase (CD) are widely used prodrug convertases. Chalikonda et al. [146] reported on the oncolytic VACV with an inserted $\mathrm{CD}$ gene; $\mathrm{CD}$ converts the nontoxic prodrug 5-fluorocytosine (5-FC) into 5-fluorouracil (5-FU) in the tumor sites, substantially enhancing the therapeutic effect owing to the presence of active drugs at the tumor sites. However, some tumor cells are resistant to 5-FU, reducing its therapeutic efficiency [147]. TG6002 is an oncolytic VACV expressing the suicide gene FCU1 [148]. FCU1 is a bifunctional gene comprising FCY1 and FUR1. FCY1 can convert 5-FC into 5-FU, and FUR1 can convert 5-FU into the more potent 5-fluorouracil-monophosphate [149], exerting a strong antitumor effect. The results of clinical trials on TG6002 have yet to be reported.

\section{ECM-degrading enzymes}

ECM in tumor tissues can inhibit the intratumoral spread of OVs and limit their antitumor efficacy [150]. Many studies have explored the effects of ECM-degrading enzymes, such as relaxin [151], matrix metalloproteinase (MMP)-9 [152], chondroitinase $\mathrm{ABC}$ [153], and $\mathrm{PH} 20$ hyaluronidase [154]; those ECM-degrading enzymes can increase the intratumoral spread of OVs and improve the antitumor activity of OVs through degrading ECM components. Therefore, expressing ECM-degrading enzymes is a feasible strategy to increase the antitumor activity of modified OVs. For example, GLV-1h255, an oncolytic VACV, can express MMP-9 to promote collagen IV degradation [152] and increase the intratumoral spread and antitumor efficacy of OV. VCN-01 is an OAd expressing PH20 hyaluronidase[155], PH20 hyaluronidase can promote the spread of OVs between tumor cells by degrading the ECM. VCN-01 has now entered clinical trials for the treatment of pancreatic adenocarcinoma and retinoblastoma [156].

\section{Anti-vasculature molecules}

Tumor vasculature can transport nutrients and oxygen to tumor cells and is crucial to the growth of tumor cells and an ideal target for antitumor therapy [157]. Previous studies have found that anti-angiogenesis factors expressed by OVs can effectively inhibit tumor angiogenesis and 
enhance the antitumor efficiency of OVs. Vascular endothelial growth factor (VEGF) can promote angiogenesis, which is an important target of cancer treatment [158]. Alexa et al. constructed an oncolytic VACV expressing scAb-targeting VEGF, and its antitumor efficiency was significantly improved [159]. In addition to targeting VEGF, OVs can express other anti-angiogenic factors, such as endostatin $[160,161]$ and thrombospondin-1 (TSP1), to destroy tumor blood vessels [162]. Endostatin can inhibit tumor angiogenesis by preventing endothelial cell migration; oncolytic HSV expressing endostatin (HSVEndo) effectively inhibited tumor angiogenesis and growth in the lung cancer model [160]. TSP-1 can inhibit tumor angiogenesis by inducing apoptosis and can improve the antitumor efficiency of OV; T-TSP-1 is an oncolytic HSV expressing TSP-1 that significantly inhibited the growth of gastric cancer in vivo [162].

\section{Monitoring OV replication}

Understanding the distribution and replication status of OVs in vivo helps in assessing the efficacy and safety of OVs [163]. OV replication can be monitored by incorporating them with reporter genes, such GFP and Rluc (usually used for optical imaging), NIS, and human norepinephrine transporter (NET) (usually used for deep tissue imaging) [164]. GFP insertion is widely used in OVT, and multiple OVs expressing GFP have been developed, such as MV-GFP (MV) [165], JX-GFP (VACV) [104], and rFMW/GFP (NDV) [166]. With the expression of GFP, fluorescence imaging can be used to directly observe the localization of OVs. However, monitoring OVs or tumors in deep tissues via GFP and Rluc is difficult, whereas NIS or NET can be used to monitor OV replication in deep tissues [164]. NIS is a membrane ion channel that mediates iodine transport. After NIS expressed by OVs takes up the iodide isotope, OV localization can be monitored using single-photon emission computed tomography or positron emission tomography [26,167]. MV-NIS is an oncolytic MV expressing NIS, and it has entered clinical trials for the treatment of multiple myeloma [21].

In addition to the insertion of reporter genes, the replication status of $\mathrm{OV}$ in vivo can be reflected by the expression of soluble markers [168], such as CEA. MVCEA is an oncolytic MV expressing CEA; the serum CEA level can reflect the replication status of MV in vivo [169], but it cannot be used for localization.

\section{Combination of OVT and other immunotherapies}

When OVs are used as monotherapy, their antitumor efficacy can be limited by many factors [186]. Pre-existing antiviral immunity in human bodies could clear OVs rapidly [187]; the heterogeneity of tumor cells might result in the low efficient replication and spread of OVs [187]; the expression of immune checkpoint molecules might limit the antitumor activity of immune cells, which were attracted into the TME by OVs [51]. Researchers have begun to combine OVT with other antitumor therapies, particularly immunotherapies, including ICB (programmed cell death protein 1 (PD-1)/programmed death ligand 1 (PD-L1) and cytotoxic T-lymphocyte-associated protein 4 (CTLA-4) signaling pathway blockade), and CAR-T cell therapies, to further improve the antitumor efficacy of OVs.

\section{Combinations of OVs and ICB}

ICB involves using ICIs to bind to immune checkpoint receptors or ligands and block immune inhibitory signals to treat cancer $[188,189]$. The PD-1/PD-L1 and CTLA-4 pathways are two important immune inhibitory pathways. Several monoclonal antibodies blocking these two pathways have been approved by the US FDA. The treatment of some tumor types by using ICB is successful [190,191], but many factors that induce resistance of tumor cells to ICB, such as CD8 T cell deficiency in tumor tissues and low expression of immune signal molecules (such as PDL1), have restricted the antitumor efficacy of ICB $[192,193]$; many patients also did not benefit from immune checkpoint therapy. Therefore, combinations of OVs with ICB have been widely explored in antitumor research to achieve better outcomes, and some combination therapies have been evaluated in clinical trials (Table 3). The combination of OVs and ICB can exert a synergistic effect. OVs can attract CD8 $\mathrm{T}$ cells and natural killer (NK) cells into the TME. This phenomenon addresses the lack of immune cells in the TME and consequent inability of antibodies targeting the PD-1/PD-L1 and CTLA-4 pathways. Anti-PD-1/PD-L1 antibodies can block the PD-L1 induced by OVs (Fig. 3A), and anti-CTLA-4 antibodies can block the corresponding inhibitory signaling pathway and enhance the antitumor activity of immune cells attracted by OVs.

\section{Combinations of OVs and PD-1/PD-L1 blockade}

To date, six monoclonal antibodies targeting the PD-1/PDL1 pathway have been approved by the US FDA for clinical use; among such antibodies, pembrolizumab, nivolumab, and cemiplimab are anti-PD-1 antibodies $[209,210]$, whereas durvalumab, atezolizumab, and avelumab are anti-PD-L1 antibodies [211]. Tumeh et al. [212] analyzed samples from patients with melanoma in the phase I clinical trials of pembrolizumab and found that the CD8 $T$ cell density at the tumor site was significantly lower in patients who did not respond to pembrolizumab 
A

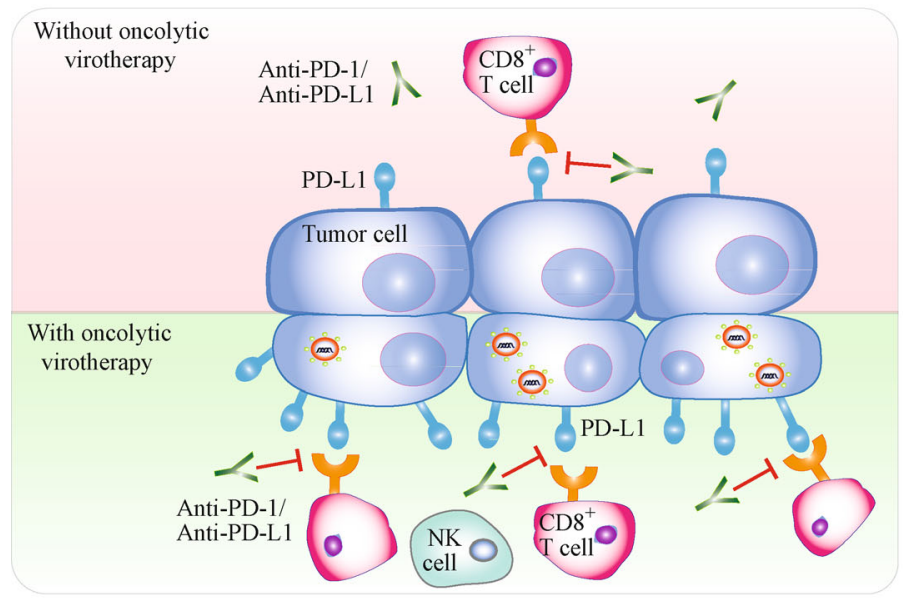

B

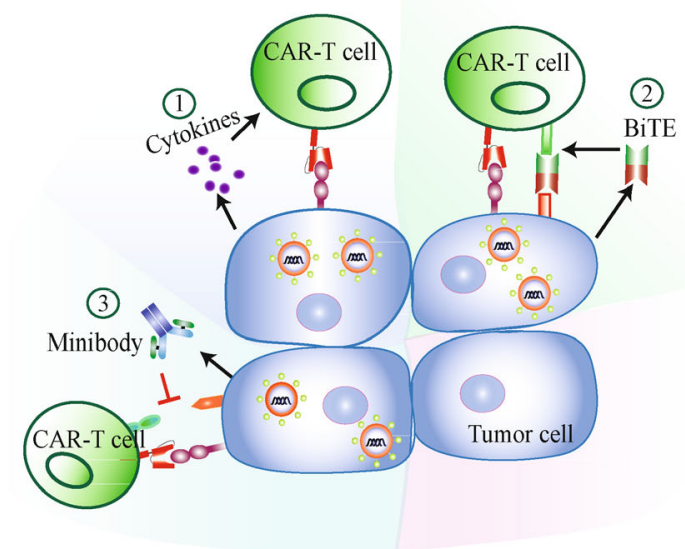

Fig. 3 Combinations of oncolytic viruses with immune checkpoint inhibitors and CAR-T cell therapy. (A) Mechanisms of OVs combined with ICIs targeting the programmed cell death protein 1 (PD-1)/programmed cell death 1 ligand 1 (PD-L1) pathway. OVs can attract CD8 T cells and NK cells into the TME. The expression of PD-L1 on tumor cells is upregulated by OV infection. Anti-PD-1/PD-L1 antibodies block the PD-1/PD-L1 pathway and stop the immune inhibitory signal. (B) OVs in combination with CAR-T cells in the treatment of solid tumors. Modified OVs can express cytokines that attract CAR-T cells into the TME and enhance their antitumor activities; BiTE-armed OVs express BiTEs that bridge CAR-T cells with tumor cells to prevent the immune evasion of tumor cells; OVs armed with anti-PD1/PD-L1 mini-antibody (mini-body) express anti-PD-1/PD-L1 mini-body blocking the immune inhibitory signal and enhancing the antitumor efficacy of CAR-T cells.

compared with that of patients who responded to pembrolizumab. CD8 T cell deficiency in the TME is an important factor underlying the low efficacy of anti-PD-1 treatment. Studies have reported that OVs can increase the number of CD8 T cells in the TME and peripheral blood [28,213,214], which is helpful in improving the therapeutic effect of PD-1/PD-L1 blockade [189]. OV infections can upregulate PD-L1 expression on the surface of tumor cells [7,194,196,200], while PD-1/PD-L1 blocking antibodies can block the PD-1/PD-L1 signaling pathway. Therefore, combining OVs with PD-1/PD-L1 blockade has synergistic roles in increasing antitumor effects.

Chen et al. reported that combining oncolytic HSV-1716 with PD-1 blockade has a pronounced antitumor effect in murine rhabdomyosarcoma models compared with oncolytic HSV-1716 or anti-PD-1 antibody monotherapy; this improvement is associated with an increase in local antitumor $\mathrm{T}$ cell immune response [195]. Liu et al. combined oncolytic VACV with PD-L1 blocking antibody, which effectively inhibited tumor growth and improved the survival of experimental mice ( $>40 \%$ experimental mice were cured) [194] in colon cancer and ovarian cancer models. Fend et al. reported that combining the WR strain of VACV with ICB effectively improved the survival of experimental animals with MCA205 sarcoma [199]. Samson et al. combined oncolytic reovirus with ICB to treat brain tumors and found that sequential treatment with oncolytic reovirus and PD-1/PD-L1 blocking antibody effectively improved the survival of experimental mice with glioma [7]. Marie-Claude et al. also reported that oncolytic Maraba virus can induce long-term antitumor immunity and improve the immunosuppressive status of the TME, enhancing the sensitivity of TNBC to ICB [10]. In the treatment of non-solid tumors, such as acute myeloid leukemia (AML), the combination of OV and PD-1/PD-L1 blockade also produced promising outcomes. Shen et al. reported that oncolytic VSV (VSV-IFN $\beta$-NIS) combined with anti-PD-L1 antibodies effectively killed murine AML cells and significantly improved the survival of AMLbearing mice [197].

Combinations of OVs and anti-PD-1/PD-L1 antibodies have been assessed in clinical trials. Ribas et al. reported the results of a phase Ib clinical trial of intratumoral T-VEC injection combined with pembrolizumab for the treatment of patients with advanced melanoma [200]. T-VEC enhanced the infiltration of CD4 and CD8 T cells and promoted the PD-L1 expression in tumor tissues, thereby improving the efficacy of pembrolizumab that led to an overall response rate of $62 \%$ and a complete response rate of $33 \%$. This combination therapy did not increase toxicity compared with pembrolizumab monotherapy. Sun et al. reported the results of a clinical trial of T-VEC combined 


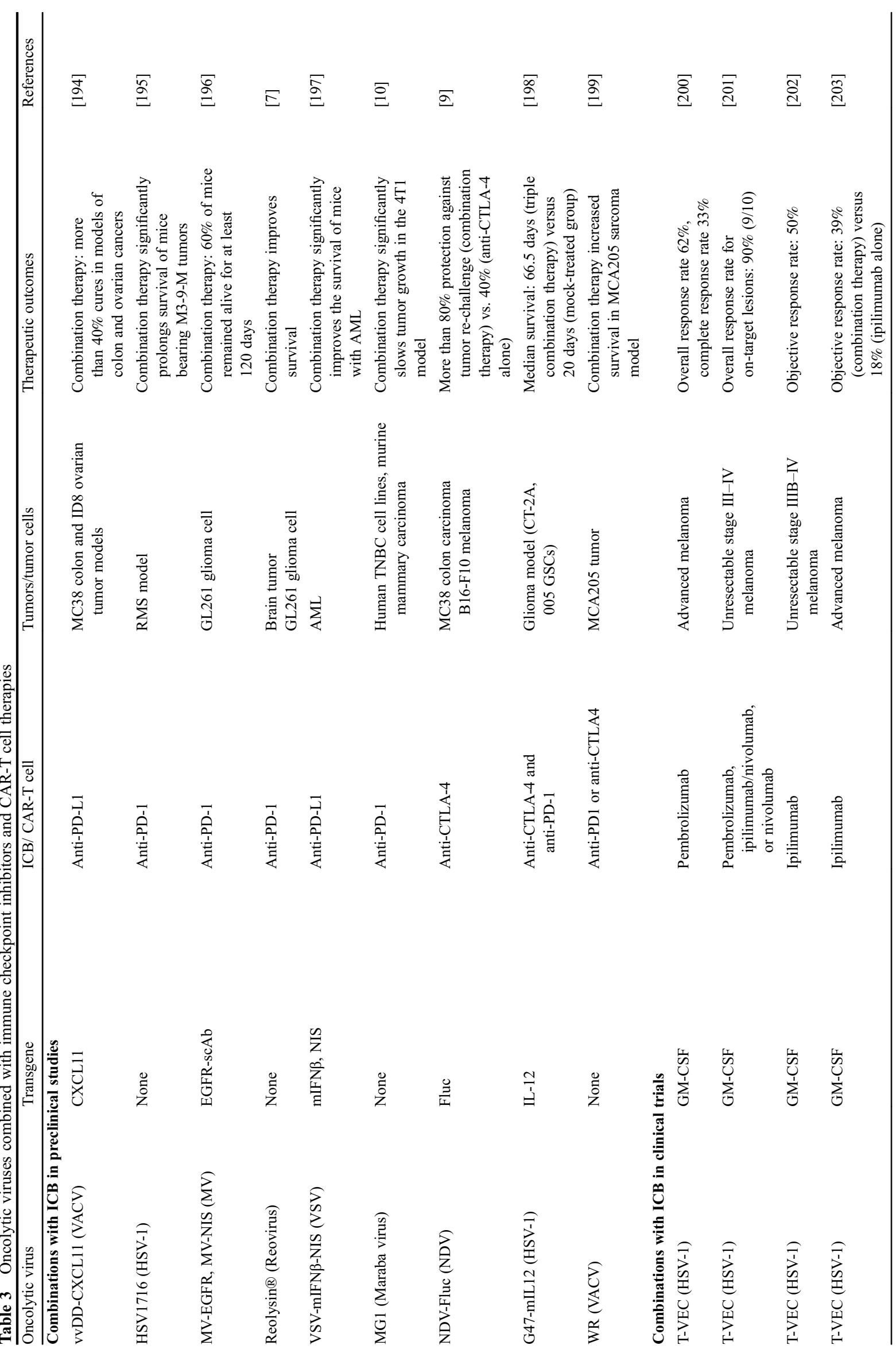




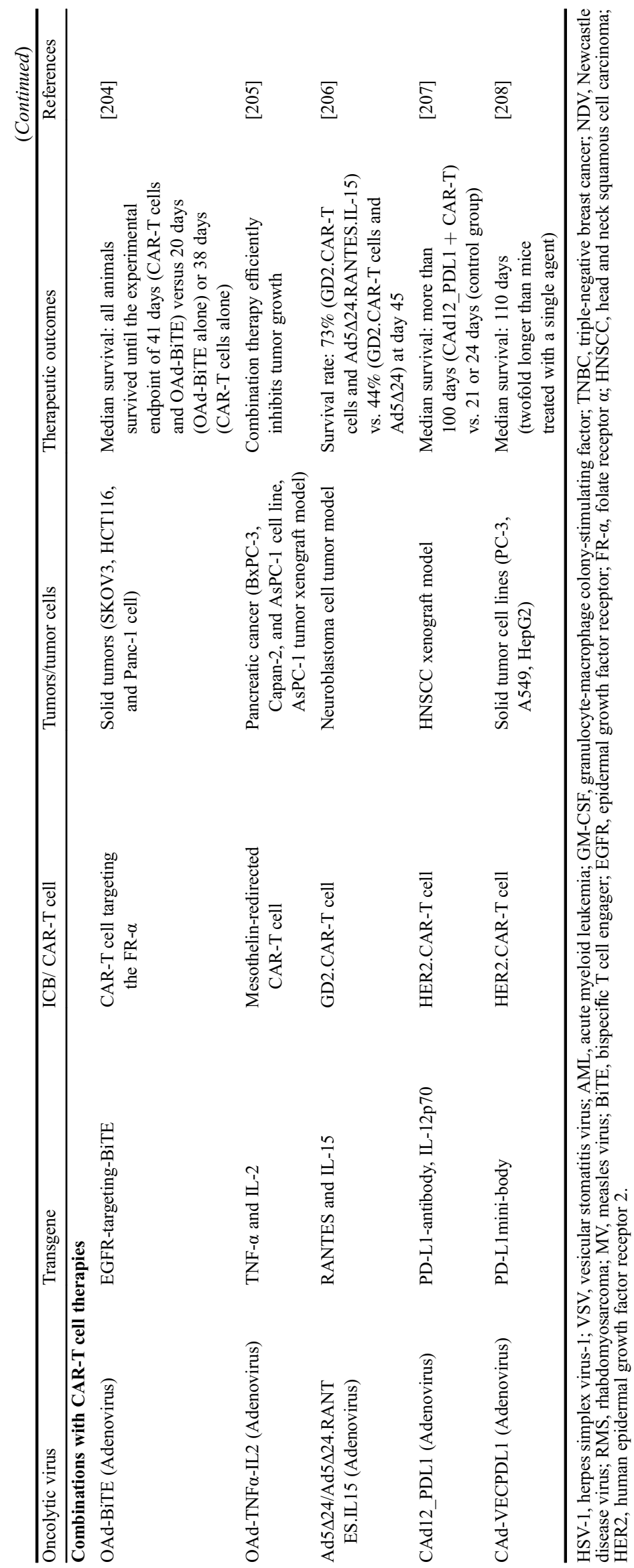


with anti-PD-1 antibody for unresectable stage III-IV melanoma treatment, leading to an overall response rate (on-target lesions) of 90\% (9/10) [201].

\section{Combinations of OVs and CTLA-4 blockade}

Zamarin et al. studied the combination of NDV and CTLA4 blockade in the syngeneic mouse model [9]. The combination generated a synergistic effect, inhibiting the growth of local tumors. In addition, lymphocyte infiltration induced by NDV increased the sensitivity of distal tumor cells (where no OV was injected) to CTLA-4 blockade. Among the CTLA-4 blocking antibodies, ipilimumab has been approved by the US FDA for the treatment of melanoma [215]. In 2018, the results of the phase II clinical trial of T-VEC combined with ipilimumab for melanoma treatment were reported [203], and phase Ib trial results were reported previously [202]. The combination of the two therapies increased antitumor efficacy compared with ipilimumab alone [203] (ORR: 39\% versus 18\%) with no reduction in safety.

Comprehensive combination regimens have been used for some tumors with a highly immunosuppressed TME. GBM is one of the most lethal tumors, and its TME is highly immunosuppressed. A standalone ICI may not overcome the immunosuppressive state. Saha et al. combined anti-PD-1 antibody, anti-CTLA-4 antibody, and oncolytic HSV expressing IL-12 (G47-mIL-12) for GBM treatment [198]. Compared with dual therapy using anti-PD-1 and anti-CTLA-4 antibodies, triple therapy, including anti-PD-1 antibody, anti-CTLA-4 antibody, and G47-mIL-12, cured most experimental mice with 005 GSC GBM and significantly improved the survival of the CT-2A implanted mice. The median survival of CT-2A implanted mice was $66.5,20$, and 19 days for the triple therapy, mock treatment, and dual antibody therapy, respectively. Triple therapy can effectively trigger immune memory and prevent tumor recurrence compared with dual therapy.

\section{Combinations of OVs and CAR-T cell therapies}

CAR-T cell therapy show considerable promise in cancer treatment. This therapy involves CAR-T cells derived from patients' $T$ cells with an additional insertion of the chimeric antigen receptor (CAR) gene to enhance tumor cell recognition [216]. CAR-T cells targeting CD19 is the first CAR-T cell therapy approved by the US FDA for the treatment of B cell lymphoma [217]. CAR consists of an extracellular antigen recognition domain, a transmembrane region, and an intracellular signal domain [218]. The antigen recognition domain is an antibody fragment that recognizes targeted antigens. The intracellular signaling domain stimulates T cell activation and proliferation to kill target cells [219]. CAR-T cell therapies are successful in the treatment of several hematopoietic malignancies
[220,221] but not in the treatment of solid tumors [222]; the immunosuppressive TME is a major obstacle to the role of CAR-T cells [223]. Given the many types of immunesuppressive cells, such as regulatory $\mathrm{T}$ cells (Tregs) and myeloid-derived suppressor cells (MDSCs) in the TME [224], and the lack of chemokines to attract tumor-specific $\mathrm{T}$ cells, the therapeutic efficacy of CAR-T cell therapy in solid tumors is limited [222].

Combining CAR-T cell therapy with genetically modified OVs can significantly increase CAR-T cell infiltration into the TME and enhance the therapeutic effect of CAR-T cells in solid tumors, as shown in Fig. 3B. Those modified OVs can attract CAR-T cells to the TME via cytokine expression. Nishio et al. inserted the genes encoding a chemokine (RANTES) and a cytokine (IL-15) into OAd to create Ad5 $\triangle 24$.RANTES.IL-15. The intratumoral injection of Ad5 24 .RANTES.IL-15 increased the infiltration of CAR-T cells targeting the tumor antigen GD2 (GD2. CAR-T cells) into the TME, thereby enhancing their tumor-killing ability [206]. Watanabe et al. constructed an AdV expressing TNF- $\alpha$ and IL-2 (OAd-TNFa-IL2) and proved that it could enhance the function of CAR-T cells [205].

Bispecific $\mathrm{T}$ cell engager (BiTE) is a fusion protein composed of two scAb fragments; one targets specific molecules on the surface of tumor cells, and the other binds to $\mathrm{CD} 3 \epsilon$ on the surface of T cells [225]. BiTE can bridge T cells and tumor cells, thereby promoting T cell activation to kill tumor cells [226]. Blinatumomab (BiTE targeting CD19) has been approved by the US FDA for the treatment of $B$ cell acute lymphoblastic leukemia [227]. The combination of OV expressing BiTE with CAR-T cells can also produce potent antitumor activity [228]. Folate receptor $\alpha(\mathrm{FR}-\alpha)$, highly expressed in ovarian, breast, and lung tumor cells, is an important target for antitumor therapy [229]. However, small partial tumor cells remain with low or even no expression of FR- $\alpha$ in those tumor lesions that can lead to immune escape. Wing et al. [204] constructed an OAd armed with BiTE targeting epidermal growth factor receptor (OAd-BiTE). In the combination of OAd-BiTE and anti-FR- $\alpha$ CAR-T cells, EGFR-targeting BiTE expressed by OAd bridged the EGFR-overexpressing tumor cells and CAR-T cells to promote CAR-T cell activation and proliferation, and their ability to kill tumor cells was enhanced; as such, the survival of experimental mice was prolonged. All mice treated with CAR-T cells plus OAd-BiTE survived up to the experimental endpoint of 41 days, whereas the median survival of OAd-BiTEonly mice was 20 days and that of CAR-T cells-only mice was 38 days.

Immune inhibitory molecules on the surface of cancer cells also affect the efficiency of CAR-T cell therapy. The transduction of immune checkpoint signals may decrease the therapeutic efficiency of CAR-T cells [230,231], while combinations of ICIs and CAR-T cells can increase the 
antitumor effects of CAR-T cells [232,233]. Tanoue et al. used an OAd expressing anti-PD-L1 mini-antibody (CAdVECPDL1) to block the transduction of the PD-1/PD-L1 inhibitory signaling pathway and improve the antitumor effect of CAR-T cells; the median survival of mice treated with CAd-VECPDL1 and HER2.CAR-T cells was 110 days, which is twofold longer than that of mice treated with single agent of OAd or CAR-T cells [208]. Compared with the systemic injection of anti-PD-L1 antibody, the anti-PDL1 mini-antibody (mini-body) produced by OVs mainly localized in the tumor tissue with fewer adverse events [234]. Shaw et al. constructed an OAd expressing anti-PDL1 mini-body and cytokine IL-12p70 (CAd12_PDL1) [207]. IL-12p70 expression could further promote CAR expression and enhance the tumor-killing effect. In the head and neck squamous cell carcinoma (HNSCC) xenograft model, combining CAd12_PDL1 and CAR-T cell therapy improved the median survival time of experimental animals by $>100$ days in the CAd12_PDL1 + CAR-T group versus 21 or 24 days in the untreated group. At present, combinations of OVs and CAR-T cells for cancer treatment are still at the preclinical stage and have not yet entered clinical trials (Table 3).

\section{Conclusions and future prospects}

With its development for more than 100 years, OVT has become highly efficient for cancer treatment [3]. OVs can specifically infect and kill tumor cells, remodel the immunosuppressive TME, and stimulate the systemic antitumor response. New viruses with oncolytic potential, such as M1 [75] and ZIKV [115,119], have been continuously discovered, thus further enriching OVT. Genetic modification can improve the safety and antitumor efficacy of OVs, which can be designed to carry different foreign genes to kill different kinds of tumor cells. T-VEC has been approved by the US FDA and EMA for the treatment of melanoma [41]. Some OVs, such as Pexa-Vec and Reolysin ${ }^{\circledR}$, are being assessed in phase III clinical trials.

The combination of OVT with ICB or CAR-T cell therapies can have synergistic effects, which might play an important role in clinical cancer treatment in the future. OVs can be also combined with other immunotherapies, such as tumor-infiltrating lymphocyte (TIL) therapies [235]. In TIL therapies, patients usually need to be injected with IL-2 to promote TIL proliferation, which might cause many adverse events [236]. The toxicity caused by systematic injections of high-dose IL-2 can be avoided by the intratumoral injection of OAd expressing IL-2 [237]. OVs combined with tumor-targeted monoclonal antibodies, such as trastuzumab [238] and bevacizumab [239] and some small-molecule antitumor compounds, such as trametinib [240] and NU7441 [75], can generate synergistic effects and thus have broad applications in cancer treatment.

However, some shortcomings or problems still confound the full use of OVT. For example, the small genomic capacities of some OVs, such as coxsackievirus and reovirus, limit their ability to accommodate large foreign genes that can optimize their antitumor efficacy [79]. Genetic modification by deleting virulence genes to improve the safety of OVs also reduces the antitumor efficacy of OVs [241]. Although encouraging results and broad applications have been achieved with the combination of OVT and other antitumor immunotherapies, further studies on the combination therapy schedules, including dosages, injection routes, and times, should be conducted to obtain the best antitumor efficiency.

\section{Acknowledgements}

This work was supported by grants from the National Megaprojects of China for Major Infectious Diseases (No. 2018ZX10301403 to LL), the National Natural Science Foundation of China (Nos. 81661128041,81672019 , and 81822045 to LL; No. 81630090 to SJ; No. 81701998 to QW and No. 81703571 to WX), China Postdoctoral Science Foundation (Nos. 2018M640341 and 2019T120302 to SX), and the Sanming Project of Medicine in Shenzhen (to SJ).

\section{Compliance with ethics guidelines}

Qiaoshuai Lan, Shuai Xia, Qian Wang, Wei Xu, Haiyan Huang, Shibo Jiang, and $\mathrm{Lu} \mathrm{Lu}$ declare no conflict of interest. This manuscript is a review article and does not involve a research protocol requiring approval by relevant institutional review board or ethics committee.

Open Access This article is licensed under a Creative Commons Attribution 4.0 International License, which permits use, sharing, adaptation, distribution and reproduction in any medium or format, as long as you give appropriate credit to the original author(s) and the source, provide a link to the Creative Commons licence, and indicate if changes were made.

The images or other third party material in this article are included in the article's Creative Commons licence, unless indicated otherwise in a credit line to the material. If material is not included in the article's Creative Commons licence and your intended use is not permitted by statutory regulation or exceeds the permitted use, you will need to obtain permission directly from the copyright holder.

To view a copy of this licence, visit https://creativecommons.org/ licenses/by/4.0/.

\section{References}

1. Khalil DN, Smith EL, Brentjens RJ, Wolchok JD. The future of 
cancer treatment: immunomodulation, CARs and combination immunotherapy. Nat Rev Clin Oncol 2016; 13(5): 273-290

2. Yang Y. Cancer immunotherapy: harnessing the immune system to battle cancer. J Clin Invest 2015; 125(9): 3335-3337

3. Kaufman HL, Kohlhapp FJ, Zloza A. Oncolytic viruses: a new class of immunotherapy drugs. Nat Rev Drug Discov 2015; 14(9): 642-662

4. Chiocca EA, Rabkin SD. Oncolytic viruses and their application to cancer immunotherapy. Cancer Immunol Res 2014; 2(4): 295-300

5. Yu F, Wang X, Guo ZS, Bartlett DL, Gottschalk SM, Song XT. Tcell engager-armed oncolytic vaccinia virus significantly enhances antitumor therapy. Mol Ther 2014; 22(1): 102-111

6. Wang P, Li X, Wang J, Gao D, Li Y, Li H, Chu Y, Zhang Z, Liu H, Jiang G, Cheng Z, Wang S, Dong J, Feng B, Chard LS, Lemoine NR, Wang Y. Re-designing interleukin-12 to enhance its safety and potential as an anti-tumor immunotherapeutic agent. Nat Commun 2017; 8(1): 1395

7. Samson A, Scott KJ, Taggart D, West EJ, Wilson E, Nuovo GJ, Thomson S, Corns R, Mathew RK, Fuller MJ, Kottke TJ, Thompson JM, Ilett EJ, Cockle JV, van Hille P, Sivakumar G, Polson ES, Turnbull SJ, Appleton ES, Migneco G, Rose AS, Coffey MC, Beirne DA, Collinson FJ, Ralph C, Alan Anthoney D, Twelves CJ, Furness AJ, Quezada SA, Wurdak H, Errington-Mais F, Pandha H, Harrington KJ, Selby PJ, Vile RG, Griffin SD, Stead LF, Short SC, Melcher AA. Intravenous delivery of oncolytic reovirus to brain tumor patients immunologically primes for subsequent checkpoint blockade. Sci Transl Med 2018; 10(422): eaam 7577

8. Geletneky K, Hajda J, Angelova AL, Leuchs B, Capper D, Bartsch AJ, Neumann J-O, Schöning T, Hüsing J, Beelte B, Kiprianova I, Roscher M, Bhat R, von Deimling A, Brück W, Just A, Frehtman V, Löbhard S, Terletskaia-Ladwig E, Fry J, Jochims K, Daniel V, Krebs O, Dahm M, Huber B, Unterberg A, Rommelaere J. Oncolytic H-1 parvovirus shows safety and signs of immunogenic activity in a first phase I/IIa glioblastoma trial. Mol Ther 2017; 25(12): 2620-2634

9. Zamarin D, Holmgaard RB, Subudhi SK, Park JS, Mansour M, Palese P, Merghoub T, Wolchok JD, Allison JP. Localized oncolytic virotherapy overcomes systemic tumor resistance to immune checkpoint blockade immunotherapy. Sci Transl Med 2014; 6(226): 226ra32

10. Bourgeois-Daigneault MC, Roy DG, Aitken AS, El Sayes N, Martin NT, Varette O, Falls T, St-Germain LE, Pelin A, Lichty BD, Stojdl DF, Ungerechts G, Diallo JS, Bell JC. Neoadjuvant oncolytic virotherapy before surgery sensitizes triple-negative breast cancer to immune checkpoint therapy. Sci Transl Med 2018; 10(422): eaao 1641

11. Lang FF, Conrad C, Gomez-Manzano C, Yung WKA, Sawaya R, Weinberg JS, Prabhu SS, Rao G, Fuller GN, Aldape KD, Gumin J, Vence LM, Wistuba I, Rodriguez-Canales J, Villalobos PA, Dirven CMF, Tejada S, Valle RD, Alonso MM, Ewald B, Peterkin JJ, Tufaro F, Fueyo J. Phase I study of DNX-2401 (Delta-24-RGD) oncolytic adenovirus: replication and immunotherapeutic effects in recurrent malignant glioma. J Clin Oncol 2018; 36(14): 1419-1427

12. Packiam VT, Lamm DL, Barocas DA, Trainer A, Fand B, Davis RL 3rd, Clark W, Kroeger M, Dumbadze I, Chamie K, Kader AK, Curran D, Gutheil J, Kuan A, Yeung AW, Steinberg GD. An open label, single-arm, phase II multicenter study of the safety and efficacy of CG0070 oncolytic vector regimen in patients with BCG-unresponsive non-muscle-invasive bladder cancer: interim results. Urol Oncol 2018; 36(10): 440-447

13. Mell LK, Brumund KT, Daniels GA, Advani SJ, Zakeri K, Wright ME, Onyeama SJ, Weisman RA, Sanghvi PR, Martin PJ, Szalay AA. Phase I trial of intravenous oncolytic vaccinia virus (GLONC1) with cisplatin and radiotherapy in patients with locoregionally advanced head and neck carcinoma. Clin Cancer Res 2017; 23(19): 5696-5702

14. Heo J, Reid T, Ruo L, Breitbach CJ, Rose S, Bloomston M, Cho M, Lim HY, Chung HC, Kim CW, Burke J, Lencioni R, Hickman T, Moon A, Lee YS, Kim MK, Daneshmand M, Dubois K, Longpre L, Ngo M, Rooney C, Bell JC, Rhee BG, Patt R, Hwang TH, Kirn DH. Randomized dose-finding clinical trial of oncolytic immunotherapeutic vaccinia JX-594 in liver cancer. Nat Med 2013; 19(3): 329-336

15. Kaufman HL, Bines SD. OPTIM trial: a phase III trial of an oncolytic herpes virus encoding GM-CSF for unresectable stage III or IV melanoma. Future Oncol 2010; 6(6): 941-949

16. Kasuya H, Kodera Y, Nakao A, Yamamura K, Gewen T, Zhiwen W, Hotta Y, Yamada S, Fujii T, Fukuda S, Tsurumaru N, Kuwahara T, Kikumori T, Koide Y, Fujimoto Y, Nakashima T, Hirooka Y, Shiku H, Tanaka M, Takesako K, Kondo T, Aleksic B, Kawashima H, Goto H, Nishiyama Y. Phase I dose-escalation clinical trial of HF10 oncolytic herpes virus in 17 Japanese patients with advanced cancer. Hepatogastroenterology 2014; 61(131): 599-605

17. Nüesch JP, Lacroix J, Marchini A, Rommelaere J. Molecular pathways: rodent parvoviruses-mechanisms of oncolysis and prospects for clinical cancer treatment. Clin Cancer Res 2012; 18(13): 3516-3523

18. Noonan AM, Farren MR, Geyer SM, Huang Y, Tahiri S, Ahn D, Mikhail S, Ciombor KK, Pant S, Aparo S, Sexton J, Marshall JL, Mace TA, Wu CS, El-Rayes B, Timmers CD, Zwiebel J, Lesinski GB, Villalona-Calero MA, Bekaii-Saab TS. Randomized phase 2 trial of the oncolytic virus Pelareorep (Reolysin) in upfront treatment of metastatic pancreatic adenocarcinoma. Mol Ther 2016; 24(6): 1150-1158

19. Mahalingam D, Fountzilas C, Moseley J, Noronha N, Tran H, Chakrabarty R, Selvaggi G, Coffey M, Thompson B, Sarantopoulos J. A phase II study of REOLYSIN ${ }^{\circledR}$ (pelareorep) in combination with carboplatin and paclitaxel for patients with advanced malignant melanoma. Cancer Chemother Pharmacol 2017; 79(4): 697-703

20. Tayeb S, Zakay-Rones Z, Panet A. Therapeutic potential of oncolytic Newcastle disease virus: a critical review. Oncolytic Virother 2015; 4: 49-62

21. Dispenzieri A, Tong C, LaPlant B, Lacy MQ, Laumann K, Dingli D, Zhou Y, Federspiel MJ, Gertz MA, Hayman S, Buadi F, O'Connor M, Lowe VJ, Peng KW, Russell SJ. Phase I trial of systemic administration of Edmonston strain of measles virus genetically engineered to express the sodium iodide symporter in patients with recurrent or refractory multiple myeloma. Leukemia 2017; 31(12): 2791-2798

22. Niemann J, Kühnel F. Oncolytic viruses: adenoviruses. Virus Genes 2017; 53(5): 700-706

23. Torres-Domínguez LE, McFadden G. Poxvirus oncolytic virotherapy. Expert Opin Biol Ther 2019; 19(6): 561-573 
24. Watanabe D, Goshima F. Oncolytic virotherapy by HSV. Adv Exp Med Biol 2018; 1045: 63-84

25. Angelova AL, Barf M, Geletneky K, Unterberg A, Rommelaere J. Immunotherapeutic potential of oncolytic $\mathrm{H}-1$ parvovirus: hints of glioblastoma microenvironment conversion towards immunogenicity. Viruses 2017; 9(12): 382

26. Msaouel P, Opyrchal M, Dispenzieri A, Peng KW, Federspiel MJ, Russell SJ, Galanis E. Clinical trials with oncolytic measles virus: current status and future prospects. Curr Cancer Drug Targets 2018; 18(2): 177-187

27. Schirrmacher V. Fifty years of clinical application of Newcastle disease virus: time to celebrate! Biomedicines 2016; 4(3): 16

28. Durham NM, Mulgrew K, McGlinchey K, Monks NR, Ji H, Herbst R, Suzich J, Hammond SA, Kelly EJ. Oncolytic VSV primes differential responses to immuno-oncology therapy. Mol Ther 2017; 25(8): 1917-1932

29. Brown MC, Dobrikova EY, Dobrikov MI, Walton RW, Gemberling SL, Nair SK, Desjardins A, Sampson JH, Friedman HS, Friedman AH, Tyler DS, Bigner DD, Gromeier M. Oncolytic polio virotherapy of cancer. Cancer 2014; 120(21): 3277-3286

30. Bradley S, Jakes AD, Harrington K, Pandha H, Melcher A, Errington-Mais F. Applications of coxsackievirus A21 in oncology. Oncolytic Virother 2014; 3: 47-55

31. Bourhill T, Mori Y, Rancourt DE, Shmulevitz M, Johnston RN. Going (Reo)Viral: factors promoting successful reoviral oncolytic infection. Viruses 2018; 10(8): 421

32. Wheelock EF, Dingle JH. Observations on the repeated administration of viruses to a patient with acute leukemia. A preliminary report. N Engl J Med 1964; 271(13): 645-651

33. Zygiert Z. Hodgkin's disease: remissions after measles. Lancet 1971; 297(7699): 593

34. Toolan HW, Saunders EL, Southam CM, Moore AE, Levin AG. H1 virus viremia in the human. Proc Soc Exp Biol Med 1965; 119 (3): 711-715

35. Howells A, Marelli G, Lemoine NR, Wang Y. Oncolytic virusesinteraction of virus and tumor cells in the battle to eliminate cancer. Front Oncol 2017; 7(195): 195

36. Aghi M, Martuza RL. Oncolytic viral therapies - the clinical experience. Oncogene 2005; 24(52): 7802-7816

37. Eissa IR, Bustos-Villalobos I, Ichinose T, Matsumura S, Naoe Y, Miyajima N, Morimoto D, Mukoyama N, Zhiwen W, Tanaka M, Hasegawa H, Sumigama S, Aleksic B, Kodera Y, Kasuya H. The current status and future prospects of oncolytic viruses in clinical trials against melanoma, glioma, pancreatic, and breast cancers. Cancers (Basel) 2018; 10(10): 356

38. Martuza RL, Malick A, Markert JM, Ruffner KL, Coen DM. Experimental therapy of human glioma by means of a genetically engineered virus mutant. Science 1991; 252(5007): 854-856

39. Liang M. Oncorine, the world first oncolytic virus medicine and its update in China. Curr Cancer Drug Targets 2018; 18(2): 171-176

40. Wei D, Xu J, Liu XY, Chen ZN, Bian H. Fighting cancer with viruses: oncolytic virus therapy in China. Hum Gene Ther 2018; 29 (2): 151-159

41. Kohlhapp FJ, Zloza A, Kaufman HL. Talimogene laherparepvec (T-VEC) as cancer immunotherapy. Drugs Today (Barc) 2015; 51 (9): 549-558

42. Conry RM, Westbrook B, McKee S, Norwood TG. Talimogene laherparepvec: first in class oncolytic virotherapy. Hum Vaccin Immunother 2018; 14(4): 839-846

43. Bourgeois-Daigneault MC, St-Germain LE, Roy DG, Pelin A, Aitken AS, Arulanandam R, Falls T, Garcia V, Diallo JS, Bell JC. Combination of paclitaxel and MG1 oncolytic virus as a successful strategy for breast cancer treatment. Breast Cancer Res 2016; 18 (1): 83

44. Garofalo M, Saari H, Somersalo P, Crescenti D, Kuryk L, Aksela L, Capasso C, Madetoja M, Koskinen K, Oksanen T, Mäkitie A, Jalasvuori M, Cerullo V, Ciana P, Yliperttula M. Antitumor effect of oncolytic virus and paclitaxel encapsulated in extracellular vesicles for lung cancer treatment. J Control Release 2018; 283 : 223-234

45. Binz E, Berchtold S, Beil J, Schell M, Geisler C, Smirnow I, Lauer UM. Chemovirotherapy of pancreatic adenocarcinoma by combining oncolytic vaccinia virus GLV-1h68 with nab-paclitaxel plus gemcitabine. Mol Ther Oncolytics 2017; 6: 10-21

46. Wilkinson MJ, Smith HG, McEntee G, Kyula-Currie J, Pencavel TD, Mansfield DC, Khan AA, Roulstone V, Hayes AJ, Harrington KJ. Oncolytic vaccinia virus combined with radiotherapy induces apoptotic cell death in sarcoma cells by down-regulating the inhibitors of apoptosis. Oncotarget 2016; 7(49): 81208-81222

47. O'Cathail SM, Pokrovska TD, Maughan TS, Fisher KD, Seymour LW, Hawkins MA. Combining oncolytic adenovirus with radiation - a paradigm for the future of radiosensitization. Front Oncol 2017; 7: 153

48. McKenzie BA, Zemp FJ, Pisklakova A, Narendran A, McFadden G, Lun X, Kenchappa RS, Kurz EU, Forsyth PA. In vitro screen of a small molecule inhibitor drug library identifies multiple compounds that synergize with oncolytic myxoma virus against human brain tumor-initiating cells. Neuro-oncol 2015; 17(8): 1086-1094

49. Dornan MH, Krishnan R, Macklin AM, Selman M, El Sayes N, Son HH, Davis C, Chen A, Keillor K, Le PJ, Moi C, Ou P, Pardin C, Canez CR, Le Boeuf F, Bell JC, Smith JC, Diallo JS, Boddy $\mathrm{CN}$. First-in-class small molecule potentiators of cancer virotherapy. Sci Rep 2016; 6(1): 26786

50. Ajina A, Maher J. Prospects for combined use of oncolytic viruses and CAR T-cells. J Immunother Cancer 2017; 5(1): 90

51. Chen CY, Hutzen B, Wedekind MF, Cripe TP. Oncolytic virus and PD-1/PD-L1 blockade combination therapy. Oncolytic Virother 2018; 7: 65-77

52. Russell L, Peng KW, Russell SJ, Diaz RM. Oncolytic viruses: priming time for cancer immunotherapy. BioDrugs 2019; 33(5): 485-501

53. Kelly KR, Espitia CM, Zhao W, Wu K, Visconte V, Anwer F, Calton CM, Carew JS, Nawrocki ST. Oncolytic reovirus sensitizes multiple myeloma cells to anti-PD-L1 therapy. Leukemia 2018; 32 (1): 230-233

54. Achard C, Surendran A, Wedge ME, Ungerechts G, Bell J, Ilkow CS. Lighting a fire in the tumor microenvironment using oncolytic immunotherapy. EBioMedicine 2018; 31: 17-24

55. Au GG, Lincz LF, Enno A, Shafren DR. Oncolytic coxsackievirus A21 as a novel therapy for multiple myeloma. Br J Haematol 2007; 137(2): 133-141

56. Geiss C, Kis Z, Leuchs B, Frank-Stöhr M, Schlehofer JR, Rommelaere J, Dinsart C, Lacroix J. Preclinical testing of an 
oncolytic parvovirus: standard protoparvovirus $\mathrm{H}-1 \mathrm{PV}$ efficiently induces osteosarcoma cell lysis in vitro. Viruses 2017; 9(10): 301

57. Vidal L, Pandha HS, Yap TA, White CL, Twigger K, Vile RG, Melcher A, Coffey M, Harrington KJ, DeBono JS. A phase I study of intravenous oncolytic reovirus type 3 Dearing in patients with advanced cancer. Clin Cancer Res 2008; 14(21): 7127-7137

58. Annels NE, Mansfield D, Arif M, Ballesteros-Merino C, Simpson GR, Denyer M, Sandhu SS, Melcher AA, Harrington KJ, Davies B, Au G, Grose M, Bagwan I, Fox B, Vile R, Mostafid H, Shafren D, Pandha HS. Phase I trial of an ICAM-1-targeted immunotherapeutic-coxsackievirus A21 (CVA21) as an oncolytic agent against non muscle-invasive bladder cancer. Clin Cancer Res 2019; 25 (19): 5818-5831

59. Annels NE, Mansfield D, Arif M, Ballesteros-Merino C, Simpson GR, Denyer M, Sandhu SS, Melcher AA, Harrington KJ, Davies B, Au G, Grose M, Bagwan I, Fox B, Vile R, Mostafid H, Shafren D, Pandha HS. Viral targeting of non-muscle-invasive bladder cancer and priming of antitumor immunity following intravesical coxsackievirus A21. Clin Cancer Res 2019 Aug 14. [Epub ahead of print] doi: 10.1158/1078-0432.CCR-18-4022

60. Andtbacka RHI, Curti BD, Kaufman H, Daniels GA, Nemunaitis JJ, Spitler LE, Hallmeyer S, Lutzky J, Schultz SM, Whitman ED, Zhou K, Karpathy R, Weisberg JI, Grose M, Shafren D. Final data from CALM: a phase II study of coxsackievirus A21 (CVA21) oncolytic virus immunotherapy in patients with advanced melanoma. J Clin Oncol 2015; 33(15_suppl): 9030

61. Angelova AL, Witzens-Harig M, Galabov AS, Rommelaere J. The oncolytic virotherapy era in cancer management: prospects of applying $\mathrm{H}-1$ parvovirus to treat blood and solid cancers. Front Oncol 2017; 7: 93

62. Garant KA, Shmulevitz M, Pan L, Daigle RM, Ahn DG, Gujar SA, Lee PWK. Oncolytic reovirus induces intracellular redistribution of Ras to promote apoptosis and progeny virus release. Oncogene 2016; 35(6): 771-782

63. Sborov DW, Nuovo GJ, Stiff A, Mace T, Lesinski GB, Benson DM Jr, Efebera YA, Rosko AE, Pichiorri F, Grever MR, Hofmeister CC. A phase I trial of single-agent reolysin in patients with relapsed multiple myeloma. Clin Cancer Res 2014; 20(23): 5946-5955

64. Mahalingam D, Goel S, Aparo S, Patel Arora S, Noronha N, Tran H, Chakrabarty R, Selvaggi G, Gutierrez A, Coffey M, Nawrocki ST, Nuovo G, Mita MM. A phase II study of Pelareorep $\left(\right.$ REOLYSIN $\left.^{\circledR}\right)$ in combination with gemcitabine for patients with advanced pancreatic adenocarcinoma. Cancers (Basel) 2018; 10(6): 160

65. Galanis E, Markovic SN, Suman VJ, Nuovo GJ, Vile RG, Kottke TJ, Nevala WK, Thompson MA, Lewis JE, Rumilla KM, Roulstone V, Harrington K, Linette GP, Maples WJ, Coffey M, Zwiebel J, Kendra K. Phase II trial of intravenous administration of Reolysin( $\left({ }^{\circ}\right)$ (Reovirus Serotype-3-dearing Strain) in patients with metastatic melanoma. Mol Ther 2012; 20(10): 1998-2003

66. Stiff A, Caserta E, Sborov DW, Nuovo GJ, Mo X, Schlotter SY, Canella A, Smith E, Badway J, Old M, Jaime-Ramirez AC, Yan P, Benson DM, Byrd JC, Baiocchi R, Kaur B, Hofmeister CC, Pichiorri F. Histone deacetylase inhibitors enhance the therapeutic potential of reovirus in multiple myeloma. Mol Cancer Ther 2016; 15(5):830-841

67. Ramachandran M, Yu D, Dyczynski M, Baskaran S, Zhang L,
Lulla A, Lulla V, Saul S, Nelander S, Dimberg A, Merits A, LejaJarblad J, Essand M. Safe and effective treatment of experimental neuroblastoma and glioblastoma using systemically delivered triple microRNA-detargeted oncolytic Semliki Forest Virus. Clin Cancer Res 2017; 23(6): 1519-1530

68. Quetglas JI, Labiano S, Aznar MA, Bolaños E, Azpilikueta A, Rodriguez I, Casales E, Sánchez-Paulete AR, Segura V, Smerdou C, Melero I. Virotherapy with a Semliki Forest virus-based vector encoding IL12 synergizes with PD-1/PD-L1 blockade. Cancer Immunol Res 2015; 3(5): 449-454

69. Huang PY, Guo JH, Hwang LH. Oncolytic Sindbis virus targets tumors defective in the interferon response and induces significant bystander antitumor immunity in vivo. Mol Ther 2012; 20(2): 298305

70. Lin Y, Zhang H, Liang J, Li K, Zhu W, Fu L, Wang F, Zheng X, Shi H, Wu S, Xiao X, Chen L, Tang L, Yan M, Yang X, Tan Y, Qiu P, Huang Y, Yin W, Su X, Hu H, Hu J, Yan G. Identification and characterization of alphavirus M1 as a selective oncolytic virus targeting ZAP-defective human cancers. Proc Natl Acad Sci U S A 2014; 111(42): E4504-E4512

71. Hu C, Liu Y, Lin Y, Liang JK, Zhong WW, Li K, Huang WT, Wang DJ, Yan GM, Zhu WB, Qiu JG, Gao X. Intravenous injections of the oncolytic virus M1 as a novel therapy for muscleinvasive bladder cancer. Cell Death Dis 2018; 9(3): 274

72. Liang J, Guo L, Li K, Xiao X, Zhu W, Zheng X, Hu J, Zhang H, Cai J, Yu Y, Tan Y, Li C, Liu X, Hu C, Liu Y, Qiu P, Su X, He S, Lin Y, Yan G. Inhibition of the mevalonate pathway enhances cancer cell oncolysis mediated by M1 virus. Nat Commun 2018; 9 (1): 1524

73. Zhang H, Lin Y, Li K, Liang J, Xiao X, Cai J, Tan Y, Xing F, Mai J, Li Y, Chen W, Sheng L, Gu J, Zhu W, Yin W, Qiu P, Su X, Lu B, Tian X, Liu J, Lu W, Dou Y, Huang Y, Hu B, Kang Z, Gao G, Mao Z, Cheng SY, Lu L, Bai XT, Gong S, Yan G, Hu J. Naturally existing oncolytic virus M1 is nonpathogenic for the nonhuman primates after multiple rounds of repeated intravenous injections. Hum Gene Ther 2016; 27(9): 700-711

74. Zhang H, Li K, Lin Y, Xing F, Xiao X, Cai J, Zhu W, Liang J, Tan Y, Fu L, Wang F, Yin W, Lu B, Qiu P, Su X, Gong S, Bai X, Hu J, Yan G. Targeting VCP enhances anticancer activity of oncolytic virus M1 in hepatocellular carcinoma. Sci Transl Med 2017; 9 (404): eaam7996

75. Xiao X, Liang J, Huang C, Li K, Xing F, Zhu W, Lin Z, Xu W, Wu G, Zhang J, Lin X, Tan Y, Cai J, Hu J, Chen X, Huang Y, Qin Z, Qiu P, Su X, Chen L, Lin Y, Zhang H, Yan G. DNA-PK inhibition synergizes with oncolytic virus $\mathrm{M} 1$ by inhibiting antiviral response and potentiating DNA damage. Nat Commun 2018; 9(1): 4342

76. Choi AH, O'Leary MP, Fong Y, Chen NG. From benchtop to bedside: a review of oncolytic virotherapy. Biomedicines 2016; 4 (3): 18

77. Maroun J, Muñoz-Alía M, Ammayappan A, Schulze A, Peng KW, Russell S. Designing and building oncolytic viruses. Future Virol 2017; 12(4):193-213

78. Jhawar SR, Thandoni A, Bommareddy PK, Hassan S, Kohlhapp FJ, Goyal S, Schenkel JM, Silk AW, Zloza A. Oncolytic virusesnatural and genetically engineered cancer immunotherapies. Front Oncol 2017; 7: 202

79. Bommareddy PK, Shettigar M, Kaufman HL. Integrating oncolytic viruses in combination cancer immunotherapy. Nat Rev Immunol 
2018; 18(8): 498-513

80. Miest TS, Cattaneo R. New viruses for cancer therapy: meeting clinical needs. Nat Rev Microbiol 2014; 12(1): 23-34

81. Stepanenko AA, Chekhonin VP. Tropism and transduction of oncolytic adenovirus 5 vectors in cancer therapy: focus on fiber chimerism and mosaicism, hexon and pIX. Virus Res 2018; 257: $40-51$

82. Foreman PM, Friedman GK, Cassady KA, Markert JM. Oncolytic virotherapy for the treatment of malignant glioma. Neurotherapeutics 2017; 14(2): 333-344

83. Betancourt D, Ramos JC, Barber GN. Retargeting oncolytic vesicular stomatitis virus to human T-cell lymphotropic virus type 1-associated adult T-cell leukemia. J Virol 2015; 89(23): 1178611800

84. Leoni V, Vannini A, Gatta V, Rambaldi J, Sanapo M, Barboni C, Zaghini A, Nanni P, Lollini PL, Casiraghi C, Campadelli-Fiume G. A fully-virulent retargeted oncolytic HSV armed with IL-12 elicits local immunity and vaccine therapy towards distant tumors. PLoS Pathog 2018; 14(8): e1007209

85. Menotti L, Cerretani A, Hengel H, Campadelli-Fiume G. Construction of a fully retargeted herpes simplex virus 1 recombinant capable of entering cells solely via human epidermal growth factor receptor 2. J Virol 2008; 82(20): 10153-10161

86. Alessandrini F, Menotti L, Avitabile E, Appolloni I, Ceresa D, Marubbi D, Campadelli-Fiume G, Malatesta P. Eradication of glioblastoma by immuno-virotherapy with a retargeted oncolytic HSV in a preclinical model. Oncogene 2019; 38(23): 4467-4479

87. Shibata T, Uchida H, Shiroyama T, Okubo Y, Suzuki T, Ikeda H, Yamaguchi M, Miyagawa Y, Fukuhara T, Cohen JB, Glorioso JC, Watabe T, Hamada H, Tahara H. Development of an oncolytic HSV vector fully retargeted specifically to cellular EpCAM for virus entry and cell-to-cell spread. Gene Ther 2016; 23(6): 479488

88. Uchida H, Marzulli M, Nakano K, Goins WF, Chan J, Hong CS, Mazzacurati L, Yoo JY, Haseley A, Nakashima H, Baek H, Kwon H, Kumagai I, Kuroki M, Kaur B, Chiocca EA, Grandi P, Cohen JB, Glorioso JC. Effective treatment of an orthotopic xenograft model of human glioblastoma using an EGFR-retargeted oncolytic herpes simplex virus. Mol Ther 2013; 21(3): 561-569

89. Hanahan D, Weinberg RA. Hallmarks of cancer: the next generation. Cell 2011; 144(5): 646-674

90. Pikor LA, Bell JC, Diallo JS. Oncolytic viruses: exploiting cancer's deal with the devil. Trends Cancer 2015; 1(4): 266-277

91. Kohlhapp FJ, Kaufman HL. Molecular pathways: mechanism of action for Talimogene Laherparepvec, a new oncolytic virus immunotherapy. Clin Cancer Res 2016; 22(5): 1048-1054

92. Martínez-Vélez N, Xipell E, Vera B, Acanda de la Rocha A, Zalacain M, Marrodán L, Gonzalez-Huarriz M, Toledo G, Cascallo M, Alemany R, Patiño A, Alonso MM. The oncolytic adenovirus VCN-01 as therapeutic approach against pediatric osteosarcoma. Clin Cancer Res 2016; 22(9): 2217-2225

93. Garant KA, Shmulevitz M, Pan L, Daigle RM, Ahn DG, Gujar SA, Lee PW. Oncolytic reovirus induces intracellular redistribution of Ras to promote apoptosis and progeny virus release. Oncogene 2016; 35(6): 771-782

94. Lin WH, Yeh SH, Yang WJ, Yeh KH, Fujiwara T, Nii A, Chang SS, Chen PJ. Telomerase-specific oncolytic adenoviral therapy for orthotopic hepatocellular carcinoma in $\mathrm{HBx}$ transgenic mice. Int $\mathrm{J}$ Cancer 2013; 132(6): 1451-1462

95. Li JM, Kao KC, Li LF, Yang TM, Wu CP, Horng YM, Jia WW, Yang CT. MicroRNA-145 regulates oncolytic herpes simplex virus-1 for selective killing of human non-small cell lung cancer cells. Virol J 2013; 10(1): 241

96. Fujiwara T, Shirakawa Y, Kagawa S. Telomerase-specific oncolytic virotherapy for human gastrointestinal cancer. Expert Rev Anticancer Ther 2011; 11(4): 525-532

97. Hardcastle J, Kurozumi K, Chiocca EA, Kaur B. Oncolytic viruses driven by tumor-specific promoters. Curr Cancer Drug Targets 2007; 7(2): 181-189

98. Zhang W, Ge K, Zhao Q, Zhuang X, Deng Z, Liu L, Li J, Zhang Y, Dong Y, Zhang Y, Zhang S, Liu B. A novel oHSV-1 targeting telomerase reverse transcriptase-positive cancer cells via tumorspecific promoters regulating the expression of ICP4. Oncotarget 2015; 6(24): 20345-20355

99. Taki M, Kagawa S, Nishizaki M, Mizuguchi H, Hayakawa T, Kyo S, Nagai K, Urata Y, Tanaka N, Fujiwara T. Enhanced oncolysis by a tropism-modified telomerase-specific replication-selective adenoviral agent OBP-405 ('Telomelysin-RGD'). Oncogene 2005; 24 (19): 3130-3140

100. Huang P, Kaku H, Chen J, Kashiwakura Y, Saika T, Nasu Y, Urata Y, Fujiwara T, Watanabe M, Kumon H. Potent antitumor effects of combined therapy with a telomerase-specific, replication-competent adenovirus (OBP-301) and IL-2 in a mouse model of renal cell carcinoma. Cancer Gene Ther 2010; 17(7): 484-491

101. Shayestehpour M, Moghim S, Salimi V, Jalilvand S, Yavarian J, Romani B, Mokhtari-Azad T. Targeting human breast cancer cells by an oncolytic adenovirus using microRNA-targeting strategy. Virus Res 2017; 240: 207-214

102. Leber MF, Baertsch MA, Anker SC, Henkel L, Singh HM, Bossow S, Engeland CE, Barkley R, Hoyler B, Albert J, Springfeld C, Jäger D, von Kalle C, Ungerechts G. Enhanced control of oncolytic measles virus using microRNA target sites. Mol Ther Oncolytics 2018; 9: 30-40

103. Leber MF, Bossow S, Leonard VH, Zaoui K, Grossardt C, Frenzke M, Miest T, Sawall S, Cattaneo R, von Kalle C, Ungerechts G. MicroRNA-sensitive oncolytic measles viruses for cancer-specific vector tropism. Mol Ther 2011; 19(6): 1097-1106

104. McCart JA, Ward JM, Lee J, Hu Y, Alexander HR, Libutti SK, Moss B, Bartlett DL. Systemic cancer therapy with a tumorselective vaccinia virus mutant lacking thymidine kinase and vaccinia growth factor genes. Cancer Res 2001; 61(24): 87518757

105. Badrinath N, Heo J, Yoo SY. Viruses as nanomedicine for cancer. Int J Nanomedicine 2016; 11: 4835-4847

106. Kanai R, Zaupa C, Sgubin D, Antoszczyk SJ, Martuza RL, Wakimoto H, Rabkin SD. Effect of $\gamma 34.5$ deletions on oncolytic herpes simplex virus activity in brain tumors. J Virol 2012; 86(8): 4420-4431

107. McKie EA, MacLean AR, Lewis AD, Cruickshank G, Rampling $\mathrm{R}$, Barnett SC, Kennedy PGE, Brown SM. Selective in vitro replication of herpes simplex virus type 1 (HSV-1) ICP34.5 null mutants in primary human CNS tumours - evaluation of a potentially effective clinical therapy. Br J Cancer 1996; 74(5): $745-752$ 
108. Kirn DH, Thorne SH. Targeted and armed oncolytic poxviruses: a novel multi-mechanistic therapeutic class for cancer. Nat Rev Cancer 2009; 9(1): 64-71

109. Pease DF, Kratzke RA. Oncolytic viral therapy for mesothelioma. Front Oncol 2017; 7: 179

110. Jefferson A, Cadet VE, Hielscher A. The mechanisms of genetically modified vaccinia viruses for the treatment of cancer. Crit Rev Oncol Hematol 2015; 95(3): 407-416

111. Lauer UM, Schell M, Beil J, Berchtold S, Koppenhöfer U, Glatzle J, Königsrainer A, Möhle R, Nann D, Fend F, Pfannenberg C, Bitzer M, Malek NP. Phase I study of oncolytic vaccinia virus GL$\mathrm{ONC1}$ in patients with peritoneal carcinomatosis. Clin Cancer Res 2018; 24(18): 4388-4398

112. Johnson DB, Puzanov I, Kelley MC. Talimogene laherparepvec (TVEC) for the treatment of advanced melanoma. Immunotherapy 2015; 7(6): 611-619

113. Grigg C, Blake Z, Gartrell R, Sacher A, Taback B, Saenger Y. Talimogene laherparepvec (T-Vec) for the treatment of melanoma and other cancers. Semin Oncol 2016; 43(6): 638-646

114. Masoud SJ, Hu JB, Beasley GM, Stewart JH 4th, Mosca PJ. Efficacy of Talimogene Laherparepvec (T-VEC) therapy in patients with in-transit melanoma metastasis decreases with increasing lesion size. Ann Surg Oncol 2019; 26(13): 4633-4641

115. Zhu Z, Gorman MJ, McKenzie LD, Chai JN, Hubert CG, Prager BC, Fernandez E, Richner JM, Zhang R, Shan C, Tycksen E, Wang X, Shi PY, Diamond MS, Rich JN, Chheda MG. Zika virus has oncolytic activity against glioblastoma stem cells. J Exp Med 2017; 214(10): 2843-2857

116. Wikan N, Smith DR. Zika virus: history of a newly emerging arbovirus. Lancet Infect Dis 2016; 16(7): e119-e126

117. Yun SI, Lee YM. Zika virus: an emerging flavivirus. J Microbiol 2017; 55(3): 204-219

118. Shan C, Muruato AE, Nunes BTD, Luo H, Xie X, Medeiros DBA, Wakamiya M, Tesh RB, Barrett AD, Wang T, Weaver SC, Vasconcelos PFC, Rossi SL, Shi PY. A live-attenuated Zika virus vaccine candidate induces sterilizing immunity in mouse models. Nat Med 2017; 23(6): 763-767

119. Chen Q, Wu J, Ye Q, Ma F, Zhu Q, Wu Y, Shan C, Xie X, Li D, Zhan X, Li C, Li XF, Qin X, Zhao T, Wu H, Shi PY, Man J, Qin CF. Treatment of human glioblastoma with a live attenuated Zika virus vaccine candidate. MBio 2018; 9(5): e01683-18

120. Shan C, Xie X, Shi PY. Zika virus vaccine: progress and challenges. Cell Host Microbe 2018; 24(1): 12-17

121. Zeh HJ, Downs-Canner S, McCart JA, Guo ZS, Rao UN, Ramalingam L, Thorne SH, Jones HL, Kalinski P, Wieckowski E, O'Malley ME, Daneshmand M, Hu K, Bell JC, Hwang TH, Moon A, Breitbach CJ, Kirn DH, Bartlett DL. First-in-man study of western reserve strain oncolytic vaccinia virus: safety, systemic spread, and antitumor activity. Mol Ther 2015; 23(1): 202-214

122. Breitbach CJ, De Silva NS, Falls TJ, Aladl U, Evgin L, Paterson J, Sun YY, Roy DG, Rintoul JL, Daneshmand M, Parato K, Stanford MM, Lichty BD, Fenster A, Kirn D, Atkins H, Bell JC. Targeting tumor vasculature with an oncolytic virus. Mol Ther 2011; 19(5): 886-894

123. Breitbach CJ, Arulanandam R, De Silva N, Thorne SH, Patt R, Daneshmand M, Moon A, Ilkow C, Burke J, Hwang TH, Heo J, Cho M, Chen H, Angarita FA, Addison C, McCart JA, Bell JC,
Kirn DH. Oncolytic vaccinia virus disrupts tumor-associated vasculature in humans. Cancer Res 2013; 73(4): 1265-1275

124. Hamid O, Hoffner B, Gasal E, Hong J, Carvajal RD. Oncolytic immunotherapy: unlocking the potential of viruses to help target cancer. Cancer Immunol Immunother 2017; 66(10): 1249-1264

125. Cody JJ, Hurst DR. Promising oncolytic agents for metastatic breast cancer treatment. Oncolytic Virother 2015; 4: 63-73

126. Pearl TM, Markert JM, Cassady KA, Ghonime MG. Oncolytic virus-based cytokine expression to improve immune activity in brain and solid tumors. Mol Ther Oncolytics 2019; 13: 14-21

127. Roth JC, Cassady KA, Cody JJ, Parker JN, Price KH, Coleman JM, Peggins JO, Noker PE, Powers NW, Grimes SD, Carroll SL, Gillespie GY, Whitley RJ, Markert JM. Evaluation of the safety and biodistribution of M032, an attenuated herpes simplex virus type 1 expressing hIL-12, after intracerebral administration to aotus nonhuman primates. Hum Gene Ther Clin Dev 2014; 25(1): $16-27$

128. Patel DM, Foreman PM, Nabors LB, Riley KO, Gillespie GY, Markert JM. Design of a phase I clinical trial to evaluate M032, a genetically engineered HSV-1 expressing IL-12, in patients with recurrent/progressive glioblastoma multiforme, anaplastic astrocytoma, or gliosarcoma. Hum Gene Ther Clin Dev 2016; 27(2): 69-78

129. Wu Y, He J, An Y, Wang X, Liu Y, Yan S, Ye X, Qi J, Zhu S, Yu Q, Yin J, Li D, Wang W. Recombinant Newcastle disease virus (NDV/Anh-IL-2) expressing human IL-2 as a potential candidate for suppresses growth of hepatoma therapy. J Pharmacol Sci 2016; 132(1): 24-30

130. Hock K, Laengle J, Kuznetsova I, Egorov A, Hegedus B, Dome B, Wekerle T, Sachet M, Bergmann M. Oncolytic influenza A virus expressing interleukin-15 decreases tumor growth in vivo. Surgery 2017; 161(3): 735-746

131. Puskas J, Skrombolas D, Sedlacek A, Lord E, Sullivan M, Frelinger J. Development of an attenuated interleukin-2 fusion protein that can be activated by tumour-expressed proteases. Immunology 2011; 133(2): 206-220

132. Liu Z, Ge Y, Wang H, Ma C, Feist M, Ju S, Guo ZS, Bartlett DL. Modifying the cancer-immune set point using vaccinia virus expressing re-designed interleukin-2. Nat Commun 2018; 9(1): 4682

133. Autio K, Knuuttila A, Kipar A, Pesonen S, Guse K, Parviainen S, Rajamäki M, Laitinen-Vapaavuori O, Vähä-Koskela M, Kanerva A, Hemminki A. Safety and biodistribution of a double-deleted oncolytic vaccinia virus encoding CD40 ligand in laboratory Beagles. Mol Ther Oncolytics 2014; 1: 14002

134. Huang JH, Zhang SN, Choi KJ, Choi IK, Kim JH, Lee MG, Kim $\mathrm{H}$, Yun CO. Therapeutic and tumor-specific immunity induced by combination of dendritic cells and oncolytic adenovirus expressing IL-12 and 4-1BBL. Mol Ther 2010; 18(2): 264-274

135. Moran AE, Kovacsovics-Bankowski M, Weinberg AD. The TNFRs OX40, 4-1BB, and CD40 as targets for cancer immunotherapy. Curr Opin Immunol 2013; 25(2): 230-237

136. Eriksson E, Milenova I, Wenthe J, Stahle M, Leja-Jarblad J, Ullenhag G, Dimberg A, Moreno R, Alemany R, Loskog A. Shaping the tumor stroma and sparking immune activation by CD40 and 4-1BB signaling induced by an armed oncolytic virus. Clin Cancer Res 2017; 23(19): 5846-5857 
137. Rosewell Shaw A, Suzuki M. Recent advances in oncolytic adenovirus therapies for cancer. Curr Opin Virol 2016; 21: 9-15

138. Navarro SA, Carrillo E, Griñán-Lisón C, Martín A, Perán M, Marchal JA, Boulaiz H. Cancer suicide gene therapy: a patent review. Expert Opin Ther Pat 2016; 26(9): 1095-1104

139. Zhu W, Zhang H, Shi Y, Song M, Zhu B, Wei L. Oncolytic adenovirus encoding tumor necrosis factor-related apoptosis inducing ligand (TRAIL) inhibits the growth and metastasis of triple-negative breast cancer. Cancer Biol Ther 2013; 14(11): $1016-1023$

140. Hu J, Wang H, Gu J, Liu X, Zhou X. Trail armed oncolytic poxvirus suppresses lung cancer cell by inducing apoptosis. Acta Biochim Biophys Sin (Shanghai) 2018; 50(10): 1018-1027

141. Chen S, Li YQ, Yin XZ, Li SZ, Zhu YL, Fan YY, Li WJ, Cui YL, Zhao J, Li X, Zhang QG, Jin NY. Recombinant adenoviruses expressing apoptin suppress the growth of MCF7 breast cancer cells and affect cell autophagy. Oncol Rep 2019; 41(5): 2818-2832

142. Zhou W, Dai S, Zhu H, Song Z, Cai Y, Lee JB, Li Z, Hu X, Fang B, He C, Huang X. Telomerase-specific oncolytic adenovirus expressing TRAIL suppresses peritoneal dissemination of gastric cancer. Gene Ther 2017; 24(4): 199-207

143. Liu L, Wu W, Zhu G, Liu L, Guan G, Li X, Jin N, Chi B. Therapeutic efficacy of an hTERT promoter-driven oncolytic adenovirus that expresses apoptin in gastric carcinoma. Int $\mathrm{J}$ Mol Med 2012; 30(4): 747-754

144. Schepelmann S, Springer CJ. Viral vectors for gene-directed enzyme prodrug therapy. Curr Gene Ther 2006; 6(6): 647-670

145. Zhang J, Kale V, Chen M. Gene-directed enzyme prodrug therapy. AAPS J 2015; 17(1): 102-110

146. Chalikonda S, Kivlen MH, O'Malley ME, Eric Dong XD, McCart JA, Gorry MC, Yin XY, Brown CK, Zeh HJ 3rd, Guo ZS, Bartlett DL. Oncolytic virotherapy for ovarian carcinomatosis using a replication-selective vaccinia virus armed with a yeast cytosine deaminase gene. Cancer Gene Ther 2008; 15(2): 115-125

147. Dias JD, Liikanen I, Guse K, Foloppe J, Sloniecka M, Diaconu I, Rantanen V, Eriksson M, Hakkarainen T, Lusky M, Erbs P, Escutenaire S, Kanerva A, Pesonen S, Cerullo V, Hemminki A. Targeted chemotherapy for head and neck cancer with a chimeric oncolytic adenovirus coding for bifunctional suicide protein FCU1. Clin Cancer Res 2010; 16(9): 2540-2549

148. Foloppe J, Kempf J, Futin N, Kintz J, Cordier P, Pichon C, Findeli A, Vorburger F, Quemeneur E, Erbs P. The enhanced tumor specificity of TG6002, an armed oncolytic vaccinia virus deleted in two genes involved in nucleotide metabolism. Mol Ther Oncolytics 2019; 14: 1-14

149. Erbs P, Regulier E, Kintz J, Leroy P, Poitevin Y, Exinger F, Jund $\mathrm{R}$, Mehtali M. In vivo cancer gene therapy by adenovirus-mediated transfer of a bifunctional yeast cytosine deaminase/uracil phosphoribosyltransferase fusion gene. Cancer Res 2000; 60(14): 3813-3822

150. Smith E, Breznik J, Lichty BD. Strategies to enhance viral penetration of solid tumors. Hum Gene Ther 2011; 22(9): 10531060

151. Kim JH, Lee YS, Kim H, Huang JH, Yoon AR, Yun CO. Relaxin expression from tumor-targeting adenoviruses and its intratumoral spread, apoptosis induction, and efficacy. J Natl Cancer Inst 2006; 98(20): 1482-1493
152. Schäfer S, Weibel S, Donat U, Zhang Q, Aguilar RJ, Chen NG, Szalay AA. Vaccinia virus-mediated intra-tumoral expression of matrix metalloproteinase 9 enhances oncolysis of PC-3 xenograft tumors. BMC Cancer 2012; 12(1): 366

153. Dmitrieva N, Yu L, Viapiano M, Cripe TP, Chiocca EA, Glorioso JC, Kaur B. Chondroitinase ABC I-mediated enhancement of oncolytic virus spread and antitumor efficacy. Clin Cancer Res 2011; 17(6): 1362-1372

154. Guedan S, Rojas JJ, Gros A, Mercade E, Cascallo M, Alemany R. Hyaluronidase expression by an oncolytic adenovirus enhances its intratumoral spread and suppresses tumor growth. Mol Ther 2010; 18(7): 1275-1283

155. Rodríguez-García A, Giménez-Alejandre M, Rojas JJ, Moreno R, Bazan-Peregrino M, Cascalló M, Alemany R. Safety and efficacy of VCN-01, an oncolytic adenovirus combining fiber HSG-binding domain replacement with RGD and hyaluronidase expression. Clin Cancer Res 2015; 21(6): 1406-1418

156. Pascual-Pasto G, Bazan-Peregrino M, Olaciregui NG, RestrepoPerdomo CA, Mato-Berciano A, Ottaviani D, Weber K, Correa G, Paco S, Vila-Ubach M, Cuadrado-Vilanova M, Castillo-Ecija H, Botteri G, Garcia-Gerique L, Moreno-Gilabert H, GimenezAlejandre M, Alonso-Lopez P, Farrera-Sal M, Torres-Manjon S, Ramos-Lozano D, Moreno R, Aerts I, Doz F, Cassoux N, Chapeaublanc E, Torrebadell M, Roldan M, König A, Suñol M, Claverol J, Lavarino C, Carmen de T, Fu L, Radvanyi F, Munier FL, Catalá-Mora J, Mora J, Alemany R, Cascalló M, Chantada GL, Carcaboso AM. Therapeutic targeting of the RB1 pathway in retinoblastoma with the oncolytic adenovirus VCN-01. Sci Transl Med 2019; 11(476): eaat9321

157. Viallard C, Larrivée B. Tumor angiogenesis and vascular normalization: alternative therapeutic targets. Angiogenesis 2017; 20(4): 409-426

158. Siveen KS, Prabhu K, Krishnankutty R, Kuttikrishnan S, Tsakou M, Alali FQ, Dermime S, Mohammad RM, Uddin S. Vascular endothelial growth factor (VEGF) signaling in tumour vascularization: potential and challenges. Curr Vasc Pharmacol 2017; 15 (4): 339-351

159. Frentzen A, Yu YA, Chen N, Zhang Q, Weibel S, Raab V, Szalay AA. Anti-VEGF single-chain antibody GLAF-1 encoded by oncolytic vaccinia virus significantly enhances antitumor therapy. Proc Natl Acad Sci USA 2009; 106(31): 12915-12920

160. Goodwin JM, Schmitt AD, McGinn CM, Fuchs BC, Kuruppu D, Tanabe KK, Lanuti M. Angiogenesis inhibition using an oncolytic herpes simplex virus expressing endostatin in a murine lung cancer model. Cancer Invest 2012; 30(3): 243-250

161. Hutzen B, Bid HK, Houghton PJ, Pierson CR, Powell K, Bratasz A, Raffel C, Studebaker AW. Treatment of medulloblastoma with oncolytic measles viruses expressing the angiogenesis inhibitors endostatin and angiostatin. BMC Cancer 2014; 14(1): 206

162. Tsuji T, Nakamori M, Iwahashi M, Nakamura M, Ojima T, Iida T, Katsuda M, Hayata K, Ino Y, Todo T, Yamaue H. An armed oncolytic herpes simplex virus expressing thrombospondin-1 has an enhanced in vivo antitumor effect against human gastric cancer. Int J Cancer 2013; 132(2): 485-494

163. Miller A, Russell SJ. The use of the NIS reporter gene for optimizing oncolytic virotherapy. Expert Opin Biol Ther 2016; 16(1): $15-32$ 
164. Haddad D. Genetically engineered vaccinia viruses as agents for cancer treatment, imaging, and transgene delivery. Front Oncol 2017; 7: 96

165. Domingo-Musibay E, Allen C, Kurokawa C, Hardcastle JJ, Aderca I, Msaouel P, Bansal A, Jiang H, DeGrado TR, Galanis E. Measles Edmonston vaccine strain derivatives have potent oncolytic activity against osteosarcoma. Cancer Gene Ther 2014; 21(11): 483-490

166. Jiang K, Song C, Kong L, Hu L, Lin G, Ye T, Yao G, Wang Y, Chen H, Cheng W, Barr MP, Liu Q, Zhang G, Ding C, Meng S. Recombinant oncolytic Newcastle disease virus displays antitumor activities in anaplastic thyroid cancer cells. BMC Cancer 2018; 18 (1): 746

167. Aref S, Bailey K, Fielding A. Measles to the rescue: a review of oncolytic measles virus. Viruses 2016; 8(10): 294

168. Peng KW, Facteau S, Wegman T, O'Kane D, Russell SJ. Noninvasive in vivo monitoring of trackable viruses expressing soluble marker peptides. Nat Med 2002; 8(5): 527-531

169. Robinson S, Galanis E. Potential and clinical translation of oncolytic measles viruses. Expert Opin Biol Ther 2017; 17(3): 353-363

170. Johnson DB, Puzanov I, Kelley MC. Talimogene laherparepvec (TVEC) for the treatment of advanced melanoma. Immunotherapy 2015; 7(6): 611-619

171. Bell J, McFadden G. Viruses for tumor therapy. Cell Host Microbe 2014; 15(3): 260-265

172. Andtbacka RH, Agarwala SS, Ollila DW, Hallmeyer S, Milhem M, Amatruda T, Nemunaitis JJ, Harrington KJ, Chen L, Shilkrut M, Ross M, Kaufman HL. Cutaneous head and neck melanoma in OPTiM, a randomized phase 3 trial of talimogene laherparepvec versus granulocyte-macrophage colony-stimulating factor for the treatment of unresected stage IIIB/IIIC/IV melanoma. Head Neck 2016; 38(12): 1752-1758

173. Eissa IR, Naoe Y, Bustos-Villalobos I, Ichinose T, Tanaka M, Zhiwen W, Mukoyama N, Morimoto T, Miyajima N, Hitoki H, Sumigama S, Aleksic B, Kodera Y, Kasuya H. Genomic signature of the natural oncolytic herpes simplex virus HF10 and its therapeutic role in preclinical and clinical trials. Front Oncol 2017; 7: 149

174. Martínez-Vélez N, Garcia-Moure M, Marigil M, González-Huarriz M, Puigdelloses M, Gallego Pérez-Larraya J, Zalacaín M, Marrodán L, Varela-Guruceaga M, Laspidea V, Aristu JJ, Ramos LI, Tejada-Solís S, Díez-Valle R, Jones C, Mackay A, MartínezCliment JA, García-Barchino MJ, Raabe E, Monje M, Becher OJ, Junier MP, El-Habr EA, Chneiweiss H, Aldave G, Jiang H, Fueyo J, Patiño-García A, Gomez-Manzano C, Alonso MM. The oncolytic virus Delta-24-RGD elicits an antitumor effect in pediatric glioma and DIPG mouse models. Nat Commun 2019; 10(1): 2235

175. Nakajima O, Ichimaru D, Urata Y, Fujiwara T, Horibe T, Kohno M, Kawakami K. Use of telomelysin (OBP-301) in mouse xenografts of human head and neck cancer. Oncol Rep 2009; 22 (5): 1039-1043

176. Breitbach CJ, Parato K, Burke J, Hwang TH, Bell JC, Kirn DH. Pexa-Vec double agent engineered vaccinia: oncolytic and active immunotherapeutic. Curr Opin Virol 2015; 13: 49-54

177. Singh P, Pal SK, Alex A, Agarwal N. Development of
PROSTVAC immunotherapy in prostate cancer. Future Oncol 2015; 11(15): 2137-2148

178. Felt SA, Grdzelishvili VZ. Recent advances in vesicular stomatitis virus-based oncolytic virotherapy: a 5-year update. J Gen Virol 2017; 98(12): 2895-2911

179. Brown MC, Gromeier M. Cytotoxic and immunogenic mechanisms of recombinant oncolytic poliovirus. Curr Opin Virol 2015; 13: $81-85$

180. Desjardins A, Gromeier M, Herndon JE 2nd, Beaubier N, Bolognesi DP, Friedman AH, Friedman HS, McSherry F, Muscat AM, Nair S, Peters KB, Randazzo D, Sampson JH, Vlahovic G, Harrison WT, McLendon RE, Ashley D, Bigner DD. Recurrent glioblastoma treated with recombinant poliovirus. N Engl J Med 2018; 379(2): 150-161

181. Atherton MJ, Stephenson KB, Nikota JK, Hu QN, Nguyen A, Wan Y, Lichty BD. Preclinical development of peptide vaccination combined with oncolytic MG1-E6E7 for HPV-associated cancer. Vaccine 2018; 36(16): 2181-2192

182. Gong J, Sachdev E, Mita AC, Mita MM. Clinical development of reovirus for cancer therapy: an oncolytic virus with immunemediated antitumor activity. World J Methodol 2016; 6(1):25-42

183. Geletneky K, Nüesch JPF, Angelova A, Kiprianova I, Rommelaere J. Double-faceted mechanism of parvoviral oncosuppression. Curr Opin Virol 2015; 13: 17-24

184. Hajda J, Lehmann M, Krebs O, Kieser M, Geletneky K, Jäger D, Dahm M, Huber B, Schöning T, Sedlaczek O, Stenzinger A, Halama N, Daniel V, Leuchs B, Angelova A, Rommelaere J, Engeland CE, Springfeld C, Ungerechts G. A non-controlled, single arm, open label, phase II study of intravenous and intratumoral administration of ParvOryx in patients with metastatic, inoperable pancreatic cancer: ParvOryx02 protocol. BMC Cancer 2017; 17(1): 576

185. Lorence RM, Roberts MS, O’Neil JD, Groene WS, Miller JA, Mueller SN, Bamat MK. Phase 1 clinical experience using intravenous administration of PV701, an oncolytic Newcastle disease virus. Curr Cancer Drug Targets 2007; 7(2): 157-167

186. Bauzon M, Hermiston T. Armed therapeutic viruses - a disruptive therapy on the horizon of cancer immunotherapy. Front Immunol 2014; $5: 74$

187. Nguyen A, Ho L, Wan Y. Chemotherapy and oncolytic virotherapy: advanced tactics in the war against cancer. Front Oncol 2014; 4: 145

188. Topalian SL, Drake CG, Pardoll DM. Immune checkpoint blockade: a common denominator approach to cancer therapy. Cancer Cell 2015; 27(4): 450-461

189. Pardoll DM. The blockade of immune checkpoints in cancer immunotherapy. Nat Rev Cancer 2012; 12(4): 252-264

190. Rosenberg JE, Hoffman-Censits J, Powles T, van der Heijden MS, Balar AV, Necchi A, Dawson N, O’Donnell PH, Balmanoukian A, Loriot Y, Srinivas S, Retz MM, Grivas P, Joseph RW, Galsky MD, Fleming MT, Petrylak DP, Perez-Gracia JL, Burris HA, Castellano D, Canil C, Bellmunt J, Bajorin D, Nickles D, Bourgon R, Frampton GM, Cui N, Mariathasan S, Abidoye O, Fine GD, Dreicer R. Atezolizumab in patients with locally advanced and metastatic urothelial carcinoma who have progressed following treatment with platinum-based chemotherapy: a single-arm, multicentre, phase 2 trial. Lancet 2016; 387(10031): 1909-1920 
191. Alsaab HO, Sau S, Alzhrani R, Tatiparti K, Bhise K, Kashaw SK, Iyer AK. PD-1 and PD-L1 checkpoint signaling inhibition for cancer immunotherapy: mechanism, combinations, and clinical outcome. Front Pharmacol 2017; 8: 561

192. Wang Q, Wu X. Primary and acquired resistance to PD-1/PD-L1 blockade in cancer treatment. Int Immunopharmacol 2017; 46: 210-219

193. Kalbasi A, Ribas A. Tumour-intrinsic resistance to immune checkpoint blockade. Nat Rev Immunol 2020; 20(1): 25-39

194. Liu Z, Ravindranathan R, Kalinski P, Guo ZS, Bartlett DL. Rational combination of oncolytic vaccinia virus and PD-L1 blockade works synergistically to enhance therapeutic efficacy. Nat Commun 2017; 8(1): 14754

195. Chen CY, Wang PY, Hutzen B, Sprague L, Swain HM, Love JK, Stanek JR, Boon L, Conner J, Cripe TP. Cooperation of oncolytic herpes virotherapy and PD-1 blockade in murine rhabdomyosarcoma models. Sci Rep 2017; 7(1): 2396

196. Hardcastle J, Mills L, Malo CS, Jin F, Kurokawa C, Geekiyanage H, Schroeder M, Sarkaria J, Johnson AJ, Galanis E. Immunovirotherapy with measles virus strains in combination with anti-PD-1 antibody blockade enhances antitumor activity in glioblastoma treatment. Neuro Oncol 2017; 19(4): 493-502

197. Shen W, Patnaik MM, Ruiz A, Russell SJ, Peng KW. Immunovirotherapy with vesicular stomatitis virus and PD-L1 blockade enhances therapeutic outcome in murine acute myeloid leukemia. Blood 2016; 127(11): 1449-1458

198. Saha D, Martuza RL, Rabkin SD. Macrophage polarization contributes to glioblastoma eradication by combination immunovirotherapy and immune checkpoint blockade. Cancer Cell 2017; 32(2): 253-267.e5

199. Fend L, Yamazaki T, Remy C, Fahrner C, Gantzer M, Nourtier V, Préville X, Quéméneur E, Kepp O, Adam J, Marabelle A, Pitt JM, Kroemer G, Zitvogel L. Immune checkpoint blockade, immunogenic chemotherapy or IFN- $\alpha$ blockade boost the local and abscopal effects of oncolytic virotherapy. Cancer Res 2017; 77(15): 4146-4157

200. Ribas A, Dummer R, Puzanov I, VanderWalde A, Andtbacka RHI, Michielin O, Olszanski AJ, Malvehy J, Cebon J, Fernandez E, Kirkwood JM, Gajewski TF, Chen L, Gorski KS, Anderson AA, Diede SJ, Lassman ME, Gansert J, Hodi FS, Long GV. Oncolytic virotherapy promotes intratumoral $\mathrm{T}$ cell infiltration and improves anti-PD-1 immunotherapy. Cell 2017; 170(6): 1109-1119.e10

201. Sun L, Funchain P, Song JM, Rayman P, Tannenbaum C, Ko J, Mcnamara M, Marcela Diaz-Montero C, Gastman B. Talimogene Laherparepvec combined with anti-PD-1 based immunotherapy for unresectable stage III-IV melanoma: a case series. J Immunother Cancer 2018; 6(1): 36

202. Puzanov I, Milhem MM, Minor D, Hamid O, Li A, Chen L, Chastain M, Gorski KS, Anderson A, Chou J, Kaufman HL, Andtbacka RH. Talimogene Laherparepvec in combination with ipilimumab in previously untreated, unresectable stage IIIB-IV melanoma. J Clin Oncol 2016; 34(22): 2619-2626

203. Chesney J, Puzanov I, Collichio F, Singh P, Milhem MM, Glaspy J, Hamid O, Ross M, Friedlander P, Garbe C, Logan TF, Hauschild A, Lebbé C, Chen L, Kim JJ, Gansert J, Andtbacka RHI, Kaufman HL. Randomized, open-label phase II study evaluating the efficacy and safety of Talimogene Laherparepvec in combination with ipilimumab versus ipilimumab alone in patients with advanced, unresectable melanoma. J Clin Oncol 2018; 36(17): 1658-1667

204. Wing A, Fajardo CA, Posey AD, Shaw C, Da T, Young RM, Alemany R, June CH, Guedan S. Improving CART-cell therapy of solid tumors with oncolytic virus-driven production of a bispecific T-cell engager. Cancer Immunol Res 2018; 6(5): 605-616

205. Watanabe K, Luo Y, Da T, Guedan S, Ruella M, Scholler J, Keith B, Young RM, Engels B, Sorsa S, Siurala M, Havunen R, Tähtinen $\mathrm{S}$, Hemminki A, June $\mathrm{CH}$. Pancreatic cancer therapy with combined mesothelin-redirected chimeric antigen receptor $\mathrm{T}$ cells and cytokine-armed oncolytic adenoviruses. JCI Insight 2018; 3(7): e99573

206. Nishio N, Diaconu I, Liu H, Cerullo V, Caruana I, Hoyos V, Bouchier-Hayes L, Savoldo B, Dotti G. Armed oncolytic virus enhances immune functions of chimeric antigen receptor-modified T cells in solid tumors. Cancer Res 2014; 74(18): 5195-5205

207. Rosewell Shaw A, Porter CE, Watanabe N, Tanoue K, Sikora A, Gottschalk S, Brenner MK, Suzuki M. Adenovirotherapy delivering cytokine and checkpoint inhibitor augments CAR T cells against metastatic head and neck cancer. Mol Ther 2017; 25(11): 2440-2451

208. Tanoue K, Rosewell Shaw A, Watanabe N, Porter C, Rana B, Gottschalk S, Brenner M, Suzuki M. Armed oncolytic adenovirusexpressing PD-L1 mini-body enhances antitumor effects of chimeric antigen receptor $\mathrm{T}$ cells in solid tumors. Cancer Res 2017; 77(8): 2040-2051

209. Pento JT. Monoclonal antibodies for the treatment of cancer. Anticancer Res 2017; 37(11): 5935-5939

210. [No authors listed] Cemiplimab approved for treatment of CSCC. Cancer Discov 2018; 8(12): OF2

211. Syed YY. Durvalumab: first global approval. Drugs 2017; 77(12): 1369-1376

212. Tumeh PC, Harview CL, Yearley JH, Shintaku IP, Taylor EJ, Robert L, Chmielowski B, Spasic M, Henry G, Ciobanu V, West AN, Carmona M, Kivork C, Seja E, Cherry G, Gutierrez AJ, Grogan TR, Mateus C, Tomasic G, Glaspy JA, Emerson RO, Robins H, Pierce RH, Elashoff DA, Robert C, Ribas A. PD-1 blockade induces responses by inhibiting adaptive immune resistance. Nature 2014; 515(7528): 568-571

213. Taipale K, Liikanen I, Juhila J, Karioja-Kallio A, Oksanen M, Turkki R, Linder N, Lundin J, Ristimäki A, Kanerva A, Koski A, Joensuu T, Vähä-Koskela M, Hemminki A. T-cell subsets in peripheral blood and tumors of patients treated with oncolytic adenoviruses. Mol Ther 2015; 23(5): 964-973

214. Pesonen S, Diaconu I, Kangasniemi L, Ranki T, Kanerva A, Pesonen SK, Gerdemann U, Leen AM, Kairemo K, Oksanen M, Haavisto E, Holm SL, Karioja-Kallio A, Kauppinen S, Partanen KP, Laasonen L, Joensuu T, Alanko T, Cerullo V, Hemminki A. Oncolytic immunotherapy of advanced solid tumors with a CD40L-expressing replicating adenovirus: assessment of safety and immunologic responses in patients. Cancer Res 2012; 72(7): 1621-1631

215. Letendre $\mathrm{P}$, Monga V, Milhem M, Zakharia Y. Ipilimumab: from preclinical development to future clinical perspectives in melanoma. Future Oncol 2017; 13(7): 625-636

216. Pagel JM, West HJ. Chimeric antigen receptor (CAR) T-cell therapy. JAMA Oncol 2017; 3(11): 1595 
217. Anderson JK, Mehta A. A review of chimeric antigen receptor Tcells in lymphoma. Expert Rev Hematol 2019; 12(7): 551-561

218. Mikkilineni L, Kochenderfer JN. Chimeric antigen receptor T-cell therapies for multiple myeloma. Blood 2017; 130(24): 2594-2602

219. Jackson HJ, Rafiq S, Brentjens RJ. Driving CAR T-cells forward. Nat Rev Clin Oncol 2016; 13(6): 370-383

220. Long KB, Young RM, Boesteanu AC, Davis MM, Melenhorst JJ, Lacey SF, DeGaramo DA, Levine BL, Fraietta JA. CAR T cell therapy of non-hematopoietic malignancies: detours on the road to clinical success. Front Immunol 2018; 9: 2740

221. Brentjens RJ, Davila ML, Riviere I, Park J, Wang X, Cowell LG, Bartido S, Stefanski J, Taylor C, Olszewska M, Borquez-Ojeda O, Qu J, Wasielewska T, He Q, Bernal Y, Rijo IV, Hedvat C, Kobos R, Curran K, Steinherz P, Jurcic J, Rosenblat T, Maslak P, Frattini M, Sadelain M. CD19-targeted T cells rapidly induce molecular remissions in adults with chemotherapy-refractory acute lymphoblastic leukemia. Sci Transl Med 2013; 5(177): 177ra38

222. Li J, Li W, Huang K, Zhang Y, Kupfer G, Zhao Q. Chimeric antigen receptor $\mathrm{T}$ cell (CAR-T) immunotherapy for solid tumors: lessons learned and strategies for moving forward. J Hematol Oncol 2018; 11(1): 22

223. Gajewski TF, Woo SR, Zha Y, Spaapen R, Zheng Y, Corrales L, Spranger S. Cancer immunotherapy strategies based on overcoming barriers within the tumor microenvironment. Curr Opin Immunol 2013; 25(2): 268-276

224. Lavin Y, Kobayashi S, Leader A, Amir ED, Elefant N, Bigenwald C, Remark R, Sweeney R, Becker CD, Levine JH, Meinhof K, Chow A, Kim-Shulze S, Wolf A, Medaglia C, Li H, Rytlewski JA, Emerson RO, Solovyov A, Greenbaum BD, Sanders C, Vignali M, Beasley MB, Flores R, Gnjatic S, Pe'er D, Rahman A, Amit I, Merad M. Innate immune landscape in early lung adenocarcinoma by paired single-cell analyses. Cell 2017; 169(4): 750-765.e17

225. Salter AI, Riddell SR. A BiTE from cancer's intracellular menu. Nat Biotechnol 2015; 33(10): 1040-1041

226. Huehls AM, Coupet TA, Sentman CL. Bispecific T-cell engagers for cancer immunotherapy. Immunol Cell Biol 2015; 93(3): 290296

227. Stieglmaier J, Benjamin J, Nagorsen D. Utilizing the BiTE (bispecific T-cell engager) platform for immunotherapy of cancer. Expert Opin Biol Ther 2015; 15(8): 1093-1099

228. Scott EM, Duffy MR, Freedman JD, Fisher KD, Seymour LW. Solid tumor immunotherapy with $\mathrm{T}$ cell engager-armed oncolytic viruses. Macromol Biosci 2018; 18(1): 1700187

229. Cheung A, Bax HJ, Josephs DH, Ilieva KM, Pellizzari G, Opzoomer J, Bloomfield J, Fittall M, Grigoriadis A, Figini M, Canevari S, Spicer JF, Tutt AN, Karagiannis SN. Targeting folate receptor alpha for cancer treatment. Oncotarget 2016; 7(32): 52553-52574

230. Zolov SN, Rietberg SP, Bonifant CL. Programmed cell death protein 1 activation preferentially inhibits CD28.CAR-T cells. Cytotherapy 2018; 20(10): 1259-1266

231. Cherkassky L, Morello A, Villena-Vargas J, Feng Y, Dimitrov DS,
Jones DR, Sadelain M, Adusumilli PS. Human CAR T cells with cell-intrinsic PD-1 checkpoint blockade resist tumor-mediated inhibition. J Clin Invest 2016; 126(8): 3130-3144

232. Mahoney KM, Rennert PD, Freeman GJ. Combination cancer immunotherapy and new immunomodulatory targets. Nat Rev Drug Discov 2015; 14(8): 561-584

233. Serganova I, Moroz E, Cohen I, Moroz M, Mane M, Zurita J, Shenker L, Ponomarev V, Blasberg R. Enhancement of PSMAdirected CAR adoptive immunotherapy by PD-1/PD-L1 blockade. Mol Ther Oncolytics 2017; 4: 41-54

234. Postow MA, Sidlow R, Hellmann MD. Immune-related adverse events associated with immune checkpoint blockade. N Engl J Med 2018; 378(2): 158-168

235. Svane IM, Verdegaal EM. Achievements and challenges of adoptive $\mathrm{T}$ cell therapy with tumor-infiltrating or blood-derived lymphocytes for metastatic melanoma: what is needed to achieve standard of care? Cancer Immunol Immunother 2014; 63(10): 1081-1091

236. Besser MJ, Shapira-Frommer R, Itzhaki O, Treves AJ, Zippel DB, Levy D, Kubi A, Shoshani N, Zikich D, Ohayon Y, Ohayon D, Shalmon B, Markel G, Yerushalmi R, Apter S, Ben-Nun A, Ben-Ami E, Shimoni A, Nagler A, Schachter J. Adoptive transfer of tumor-infiltrating lymphocytes in patients with metastatic melanoma: intent-to-treat analysis and efficacy after failure to prior immunotherapies. Clin Cancer Res 2013; 19(17): 47924800

237. Santos JM, Havunen R, Siurala M, Cervera-Carrascon V, Tähtinen S, Sorsa S, Anttila M, Karell P, Kanerva A, Hemminki A. Adenoviral production of interleukin-2 at the tumor site removes the need for systemic postconditioning in adoptive cell therapy. Int J Cancer 2017; 141(7): 1458-1468

238. Hamano S, Mori Y, Aoyama M, Kataoka H, Tanaka M, Ebi M, Kubota E, Mizoshita T, Tanida S, Johnston RN, Asai K, Joh T. Oncolytic reovirus combined with trastuzumab enhances antitumor efficacy through TRAIL signaling in human HER2-positive gastric cancer cells. Cancer Lett 2015; 356(2 Pt B): 846-854

239. Tan G, Kasuya H, Sahin TT, Yamamura K, Wu Z, Koide Y, Hotta Y, Shikano T, Yamada S, Kanzaki A, Fujii T, Sugimoto H, Nomoto S, Nishikawa Y, Tanaka M, Tsurumaru N, Kuwahara T, Fukuda S, Ichinose T, Kikumori T, Takeda S, Nakao A, Kodera Y. Combination therapy of oncolytic herpes simplex virus HF10 and bevacizumab against experimental model of human breast carcinoma xenograft. Int J Cancer 2015; 136(7): 1718-1730

240. Bommareddy PK, Aspromonte S, Zloza A, Rabkin SD, Kaufman HL. MEK inhibition enhances oncolytic virus immunotherapy through increased tumor cell killing and $\mathrm{T}$ cell activation. Sci Transl Med 2018; 10(471): eaau0417

241. Abdullahi S, Jäkel M, Behrend SJ, Steiger K, Topping G, Krabbe T, Colombo A, Sandig V, Schiergens TS, Thasler WE, Werner J, Lichtenthaler SF, Schmid RM, Ebert O, Altomonte J. A novel chimeric oncolytic virus vector for improved safety and efficacy as a platform for the treatment of hepatocellular carcinoma. J Virol 2018; 92(23): e01386-18 